\title{
A teatralidade fora de lugar: \\ a cena Tupinambá no triunfo de Rouen ${ }^{1}$
}

Theatrality out of place:

the Tupinambá scene in Rouen's triumph

\section{Sérgio de Carvalho}

Sérgio de Carvalho Professor Associado do Departamentos de Artes Cênicas e do PPGAC da Escola de Comunicações e Artes da Universidade de São Paulo (USP).

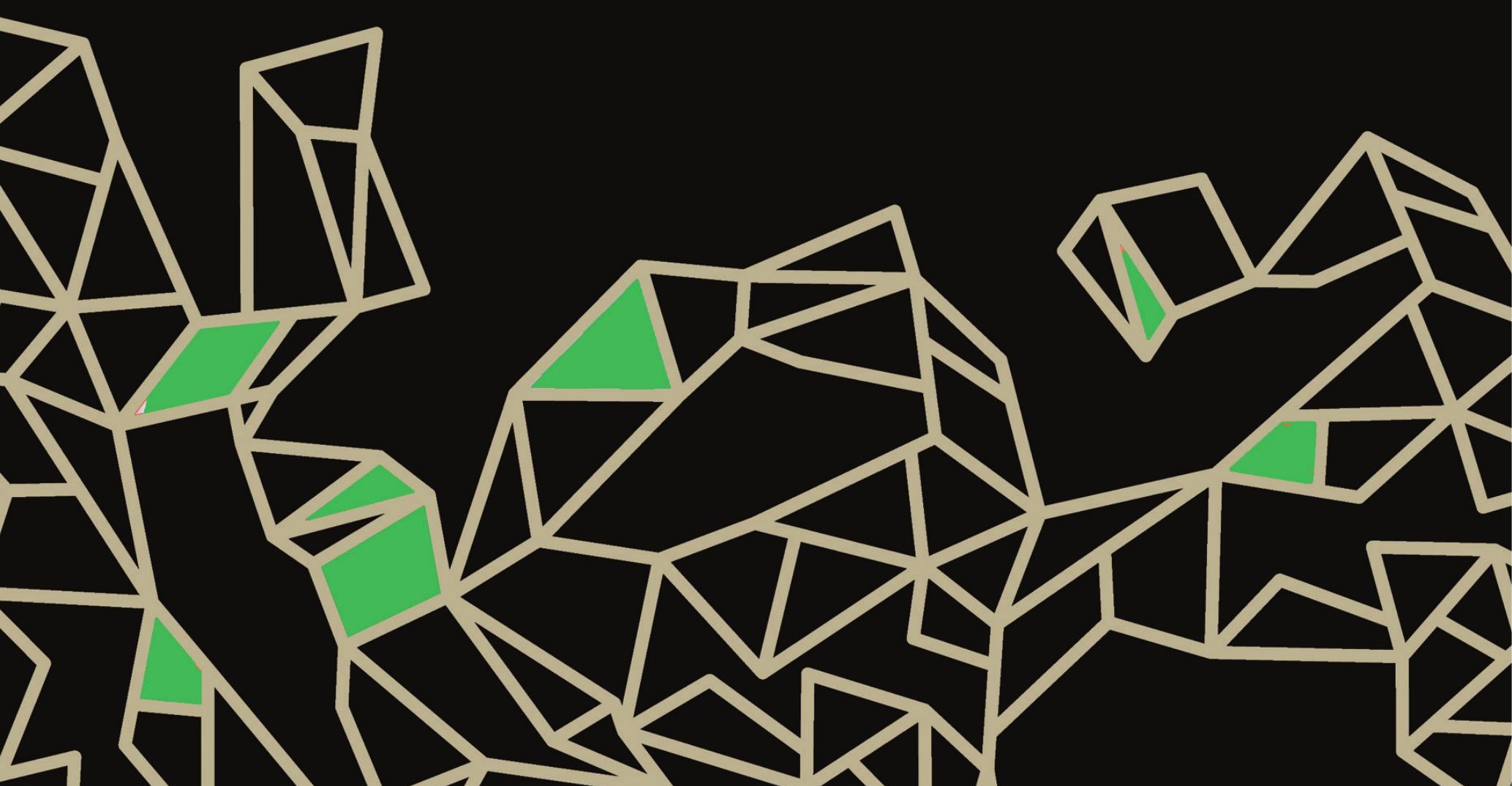




\section{Resumo}

Este texto, resultante da conferência de Sérgio de Carvalho no IFTR, discute as tensões entre os modelos culturais europeus e a vida social durante o Brasil Colônia, a partir do caso da encenação feita por tupinambás durante uma entrada real ocorrida na cidade de Rouen, França, em 1550.

Palavras-chave: História, Colônia, Tupinambás, Teatro jesuítico.

\section{Abstract}

The article, a result of Sérgio de Carvalho's lecture in IFTR, discusses the tensions between European cultural models and the social life during Colonial Brazil from tupinambás' staging during a royal entry in the city of Rouen, France, in 1550.

Keywords: History, Colony, Tupinambás, Jesuit theater.

1 Este artigo é uma versão corrigida da primeira parte da conferência "A teatralidade fora de lugar: tensões entre os modelos cênicos europeus e realidade social no Brasil", apresentada no dia 12 de julho de 2017 no encontro do IFTR (Unstable Geographies: Multiple Theatricalities), ocorrido na Universidade de São Paulo. Ele faz parte de uma pesquisa, ainda em fase inicial, sobre formas da teatralidade na colônia do Brasil, que deverá gerar um livro. Seu primeiro resultado foi o ensaio sobre o Auto de $S$. Lourenço de Anchieta, publicado em Sala Preta (v. 15, n. 1, 2015, p. 6-53), tema retomado na segunda parte desta conferência, por esta razão aqui suprimido. Na ocasião, a leitura do texto foi precedida da seguinte introdução: "Ontem, numa noite de horror histórico, o Congresso Nacional aprovou as chamadas reformas trabalhistas. Os empresários do país estão agora legalmente autorizados a fazer o que sempre fizeram: manipular as condições, o valor e o tempo de vida dos trabalhadores. Esse enorme retrocesso, que joga no lixo conquistas históricas do direito à negociação coletiva, foi comemorado nos telejornais como uma modernização necessária, como avanço da "flexibilização", sem que sua face de normalização da precariedade fosse discutida. $\mathrm{O}$ atual golpe de estado - promovido por empresários e rentistas nacionais e internacionais - veio para deixar evidente que, na periferia do capital, um trabalhador livre só pode ser um trabalhador pobre, mesmo que para isso seja preciso criar formas novas de dependência abstrata e servidão autorregulada. Inicio a palestra de hoje com este repúdio, meu e de muitos colegas, a este governo sórdido". 
Nesta conferência apresentarei alguns temas históricos ligados ao período colonial. Aproximei-me dessas questões por interesse artístico e teórico quando, há alguns anos, percebi que a historiografia convencional do teatro no Brasil tem dificuldades em compreender e analisar uma teatralidade colonial que poucas vezes se deu em padrões dramáticos, em forma dialógica. Feita antes de relações cênicas híbridas, sua dimensão estética se subordinava a outras funções sociais (como a religiosa ou a política), estando frequentemente associada a festas ou espetáculos públicos.

São muitas as razões dessa rarefação dramática entre o início da ocupação do território pelos portugueses em 1500 e a independência nacional em 1822. O estudo desse modo de teatralidade obriga o pesquisador a inscrever a produção cultural em contextos históricos muito contraditórios, a investigar relações complexas, pois só assim essas formas estéticas podem ainda "falar" - diante da mudez imposta à vida popular numa sociedade que por quase quatrocentos anos se fundou no trabalho escravo. O interesse que me conduz ao teatro da colônia, portanto, é o mesmo que move meus estudos da arte atual: procurar entender como esse país se tornou tão violentamente desigual - também no que se refere ao direito à cultura - e de algum modo lutar contra isso.

O que apresentarei são observações de uma pesquisa ainda em desenvolvimento. Com a ajuda de documentos e alguma imaginação, descreverei imagens - começando por um caso de 1550 relativo à participação de índios tupinambás num espetáculo da Europa - em que se pode visualizar de modo cru uma questão central para todo artista ou intelectual num país periférico: o choque entre o modelo cultural europeu (sempre mutante), imposto por uma imperiosa necessidade de reprodução de padrões formados no centro, e a vida social nas condições periféricas. Esses episódios podem ser lidos como documentos iniciais da dificuldade de representação dramática numa sociedade em que a ausência do trabalho livre produziu - e ainda produz - formas variadas de anulação da voz do outro.

\section{Documento do poder}

Nos dois primeiros dias de outubro do ano de 1550, na cidade francesa de Rouen, França, ocorreu uma grande festa pública para saudar o rei da 
França. Foi a primeira vez em que um grupo de índios tupinambás do Brasil atuou num espetáculo na Europa, "representando" (se é que a palavra é essa) a si próprios. Ainda que existam registros anteriores da presença de nativos do Novo Mundo em festas públicas - como a entrada de Luís XII, em 1508, na mesma Rouen -, em 1550 os índios não foram exibidos apenas como curiosidades públicas, como atrações de feira. Eles participaram ativamente de uma cena narrativa, e que pretendia reconstituir uma certa imagem de sua vida tribal no Brasil. O evento se tornou conhecido entre nós desde que o historiador Ferdinand Denis, no começo do século XIX, divulgou os relatos e batizou o episódio como "uma festa brasileira celebrada em Rouen" (2007).

A encenação de Rouen foi organizada como uma tradicional entrada triunfal (ou entrada "alegre" ou "solene"), que ocorria quando um rei visitava uma cidade em ocasiões especiais. Como se sabe, é uma modalidade de espetáculo público que se originou na Antiguidade e foi, de certo modo, reinventada na Europa do século XIII como festa de confirmação do poder monárquico diante dos súditos e vassalos, num tempo, o século das catedrais, de grande crescimento da vida urbana.

O padrão dessas entradas reais era o de uma procissão espetacular em que as autoridades cívicas e religiosas da cidade homenageavam a comitiva do rei com um recebimento fora das muralhas que dava origem a um desfile previamente preparado, entremeado por cenas e imagens alegóricas. No fim do século XV, a tradição dá sinais de configurar um padrão, podendo até mesmo ser lida como um gênero de espetáculo público: toda a cidade era decorada para o cortejo, construíam-se arcos de triunfo, pontes de madeira, carros cênicos, e grupos de atores eram ensaiados, para que, nos dias da celebração, uma grande procissão pudesse atravessar a cidade e vez ou outra estacionasse em praças ou ruas, de modo que quadros vivos com cenas alegóricas pudessem ser contemplados pelo rei e seu séquito. O rei era como que o espectador e o ator fundamental desse ato teatral organizado pela nobreza letrada e realizado pela burguesia ascendente, em que o palco da cidade desejava se inscrever na temporalidade totalizante de Deus concretizada na monarquia nacional. O tema das entradas reais é vasto e tem sido objeto de 
inúmeros estudos e controvérsias nas últimas décadas² ${ }^{2}$ De modo sintético, contudo, é possível dizer que a teatralidade processional das entradas triunfais foi contemporânea da fusão simbólica entre o poder religioso e o poder monárquico, sendo também devedora do crescimento dos mercados burgueses, havendo grande interação desse agentes no que se refere ao seu sentido formal e intenções alegóricas, que se encaminharam para hibridismos cada vez mais curiosos, capazes de misturar imaginário mitológico da Antiguidade, colecionismo do Novo Mundo, figurações do catolicismo em luta, humanismo neoplatônico e tecnologia mercantil. Entretanto, Jean Duvignaud observa que a teatralidade religiosa de uma cena processional como a da Paixão de Cristo guardaria sempre um sentido próprio quando comparada às entradas reais: na cena religiosa, a procissão parava nas estações para acumular imagens à procura de uma visão simultaneísta do tempo, que abarcasse, sob o signo da cristandade, o todo da salvação cristã; na entrada real, por sua vez, tratava-se de invadir simbolicamente a cidade, numa demonstração didática e pública do prestígio e da força divina do rei, interlocutor fundamental da encenação (DUVIGNAUD, 1965, p. 101-125).

A partir do início do século XVI, a difusão da imprensa pela Europa ajudou a que se criasse uma segunda exigência associada a esses atos festivos: a documentação por escrito do evento, sua eternização para além da memória dos vivos por meio de relatos encomendados a mestres de retórica ou poetas, muitos deles acompanhados de imagens ilustrativas. A própria festa passou a ser organizada por círculos letrados da nobreza.

A Entrada de Rouen, de que trataremos aqui, ocorreu em 1550 como homenagem ao rei francês Henrique (Henri) II. Seu minucioso relato impresso acabou por produzir um pequeno documento de uma fase inicial de relações culturais entre europeus e índios do Brasil sob a influência de um capitalismo mercantil crescente que tanto influiu na vida colonial ${ }^{3}$.

2 As obras fundamentais de Weisbach (1919) e Chartrou (1928) como que organizaram em torno dessas encenações do poder um campo de estudo que cresceu muito nas últimas décadas, com desdobramentos em áreas de conhecimento muito diversas.

3 A versão impressa de 1551 contém o seguinte título: Cest la dedvction du fumptueux ordre plaifantz fpeCTACLES ET MAGNIFIQVES THEATRES DRESSES, ET EXHIBES PAR LES CITOlens de Rouen ville Metropolitaine du pays de Normandie, A la facree Maiefté du Trefchriftian Roy de France, Henry fecôdleur fouuerain Seigneur, Et à Trefilluftre dame, ma Dame Katharine de Medicis, La Royne fon efpouze, lors leur triumphant ioyeulx \& nou- 


\section{Triunfo de Rouen}

Já nas dedicatórias da abertura fica nítido que a Entrada de Rouen foi concebida como uma superação de triunfos semelhantes feitos nos anos anteriores em Paris (1548) e Lyon (1549) ao mesmo jovem rei de França. O imaginário das entradas reais já estava associado, àquela altura, ao padrão dos triunfos militares antigos. E, naquela festa em particular, Henrique II seria saudado por sua virtude guerreira, comparável à dos heróis romanos do passado, por sua vez herdeiros dos heróis da llíada. A entrada seria, assim, o reconhecimento da cidade a um monarca que assumira a coroa há apenas três anos e acabava de chegar de uma campanha militar bem-sucedida. Meses antes, Henrique retomou dos ingleses a cidade próxima de Bolonha-sobre-o-Mar, também na Normandia, em frente ao canal da Mancha. A bem da verdade, o cerco militar só terminou com o pagamento de 400 mil coroas a Eduardo VI da Inglaterra. Mas o que importava a Rouen - ao menos do ponto de vista dos assuntos mais evidentes da encenação - era lembrar que a força militar do rei francês dependeu do apoio das famílias de cavaleiros da região, naquele momento já implicadas nos tratos econômicos do comércio marítimo e na ordem política da cidade.

O espetáculo da entrada triunfal durou dois dias. No primeiro, foi apresentado para o rei e sua comitiva. No segundo, houve reapresentação para a rainha Catarina de Médici e suas acompanhantes. As descrições existentes no texto permitem que imaginemos o ocorrido. $E$ temos a sorte de dispor de imagens que mostram o conjunto da festa e a participação dos índios tupinambás.

Às margens do Sena, relativamente próximo ao Mar do Norte, Rouen era o principal porto da França no que se refere às mercadorias vindas das Américas. Todos os navios das cidades próximas, em especial aqueles que traficavam a madeira do pau-brasil - utilizada como tingimento vermelho para tecidos -, mantinham contato com seus comerciantes e donos de navios.

uel aduenement en icelle ville, Qui fut es iours de Mercredy \& ieu dy premier \& fecôd iours d'Octobre Mil cinq cens cinquante, Et pour plus expreffe intelligence de ce tant excellent triumphe, Les figures \& pourtraictz des principaulx aornementz d'iceluy y font appofez chafcun en fon lieu comme l'on pourra veoir par le difcours de l'hiftoire. Consta da edição o nome dos livreiros: Robert le Hoy Robert \& lehan dictz du Gord, 1551 (ANÔNIMO, 1885). 
Desenhos da cidade feitos anos mais tarde, em 1575, nos ajudam a entender o possível roteiro do espetáculo.

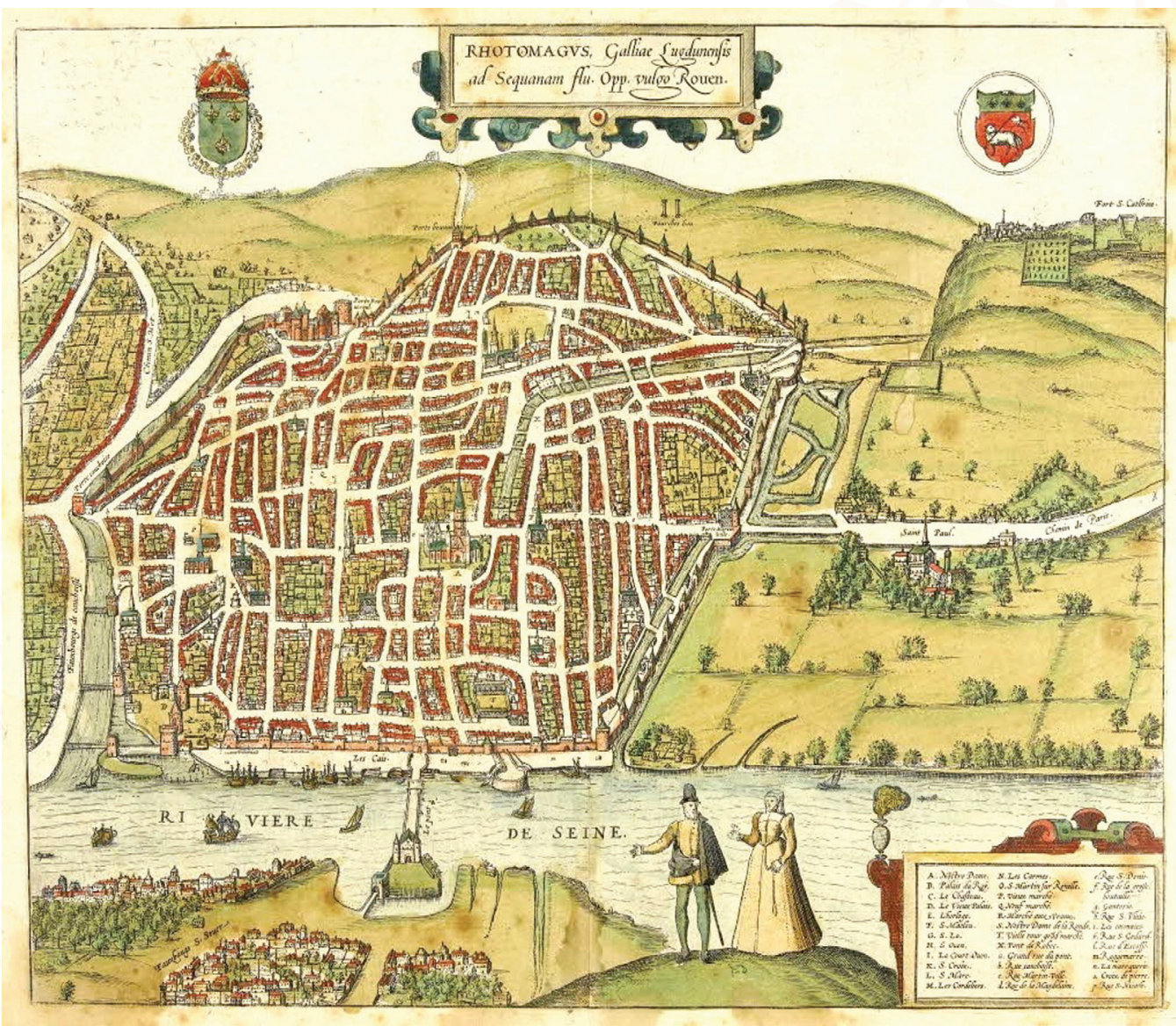

Figura 1 - Cidade de Rouen no século XVI. Na parte inferior, à esquerda, vê-se o arrabalde de Saint Sever ${ }^{4}$

Desde o domingo, dia 28 de setembro de 1550, o rei e a rainha já estavam na cidade. Vieram acompanhar a chegada de Maria Stuart de Escócia, prometida em casamento ao delfim François. Maria Stuart tinha na ocasião 7 anos de idade e assistiu à festa. Devido provavelmente ao mau tempo que adiou a entrada, a família real permaneceu reclusa na Abadia de Saint-Ouen - próxima à catedral - em encontro com nobres cavaleiros da região, membros de sua ordem militar.

No dia em que se realizou o espetáculo - uma quarta-feira, primeiro de outubro, com céu limpo, antes das sete da manhã - o séquito do rei atravessou a ponte e se dirigiu ao faubourg, ou arrabalde de Saint Sever, fora das

4 Disponível em: <https://goo.gl/RJVewC>. Acesso em: 16 out. 2017. 
muralhas da cidade, do outro lado do Sena. Ali, ao sul da Figura 2, estava construído um grande arco do triunfo, especialmente feito para a ocasião.

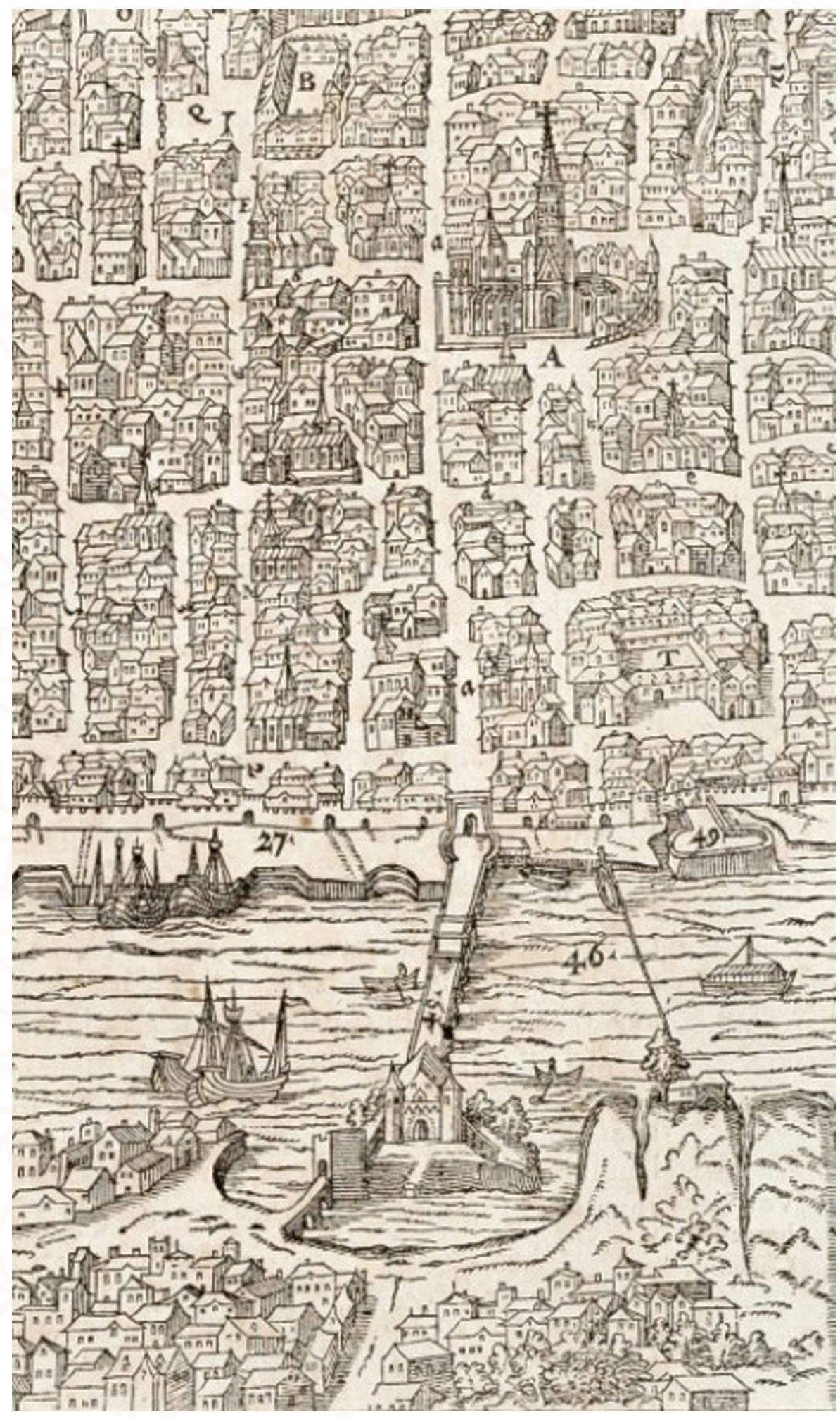

Figura 2 - Detalhe do retrato da cidade de Rouen, de François de Belleforest, de 1575 


\section{L'arc triumphal du Roy.}

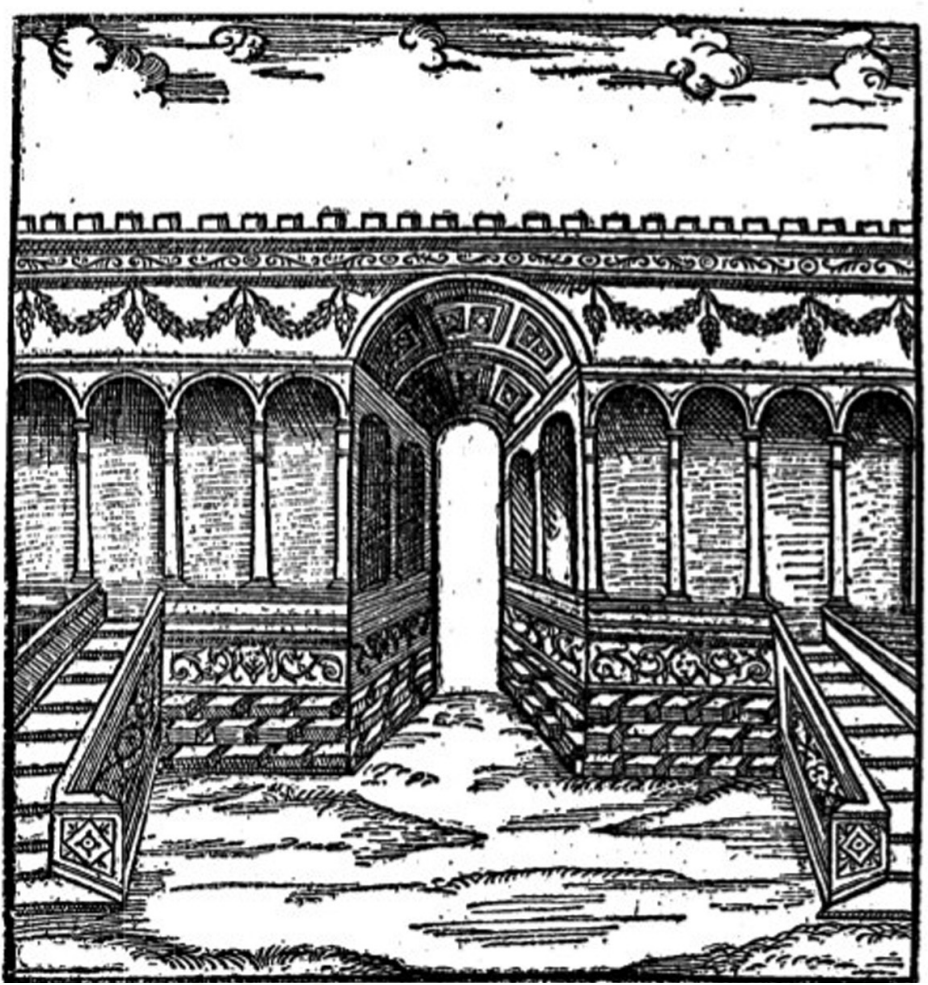

Figura 3 - Arco do triunfo

O rei sobe então a um palanque lateral ao arco do triunfo, ilustrado no documento (Figura 3). Recebe saudações do clero, dos oficiais de justiça, dos conselheiros vereadores, em suma, de todos os grupos sociais importantes da cidade, que enviaram representantes para reverenciar o rei, "cada um deles segundo seu estado e qualidade".

Neste prólogo da festa, o rei é também saudado por "honoráveis burgueses" da elite local e fica sabendo de viva voz quem foram os "principais e mais eminentes cidadãos" que se comprometeram a empregar "muito liberalmente" seu dinheiro e seus empregados nesta realização. Em suma, a cidade deixa claro que os grandes e belos arcos, teatros e carros triunfais envolveram altos custos e longa preparação.

Essa preocupação em exibir a riqueza do espetáculo atravessa o texto. Todas as descrições contêm detalhes de vestuário, enumeram as pedras preciosas e o ouro empregados, a qualidade e a origem dos tecidos e ornamentos. A riqueza do comércio mundial anuncia seu papel naquela cena de triunfo da nobreza militar. Ao meio dia, o rei ainda está num palanque próximo 
ao arco do triunfo. E é nesse momento que se inicia o espetáculo propriamente dito, quando começa o grande desfile preparado pela cidade. É uma procissão alegórica que passa por baixo do arco, abrindo alas ao rei, rumo à cidade.

De um ponto de vista da organização dos figurantes, a festa é também controlada pelo aparato militar da corte. O próprio Villegaignon, lorde almirante da França, que depois esteve no Brasil, cuida para que cinquenta arqueiros garantam a ordem da multidão de pessoas que não deve chegar perto do rei, e sim assistir a esse ato de longe, pendurada nas casas e muralhas. A abertura do cortejo espetacular é feita por cinquenta homens em armas (Figura 4).

\section{活 Les illuftres Capitaines de Normandie.}

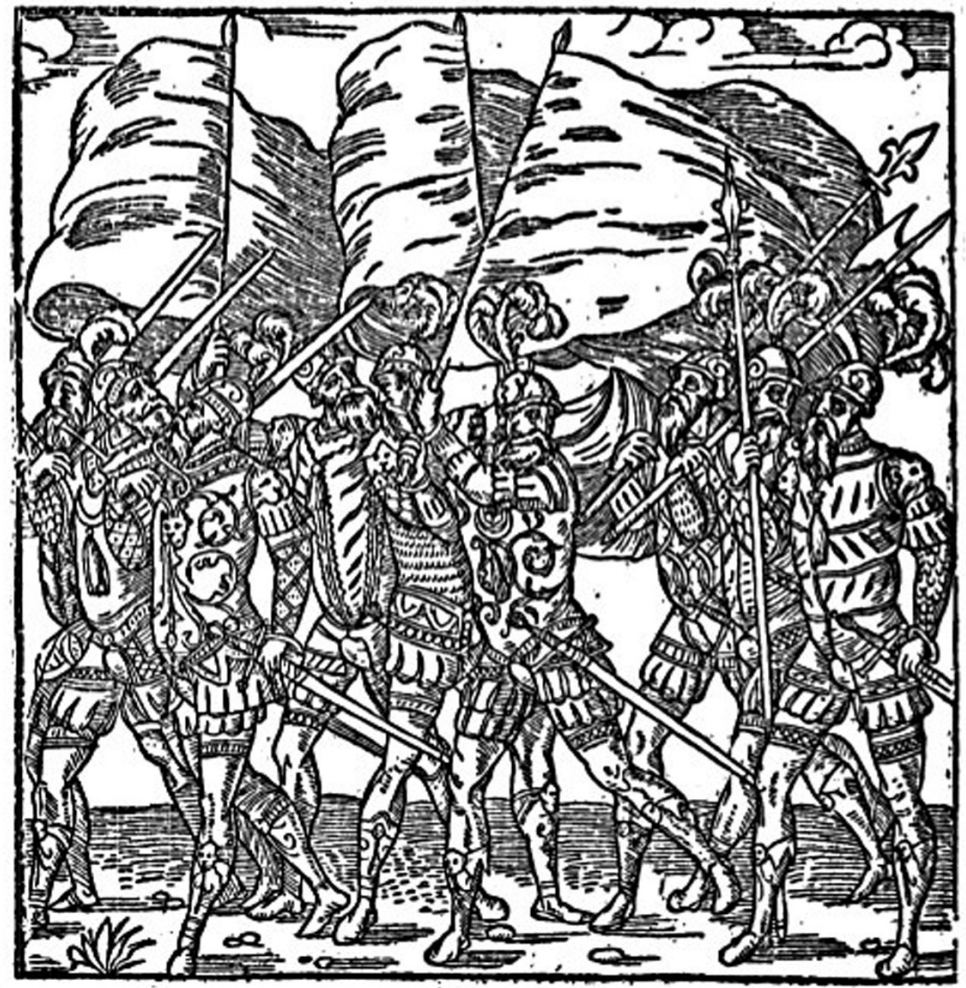

Figura 4 - Cavaleiros-capitães da Normandia

São os principais cavaleiros-capitães da Normandia, nobres militares representando a si próprios, ao certo participantes da campanha de Bolonha-sobre-o-Mar. Todos saúdam o rei. Entra, então, a primeira alegoria triunfal sobre um carro cênico: a Renomada ou a Celebridade (Figura 5). 


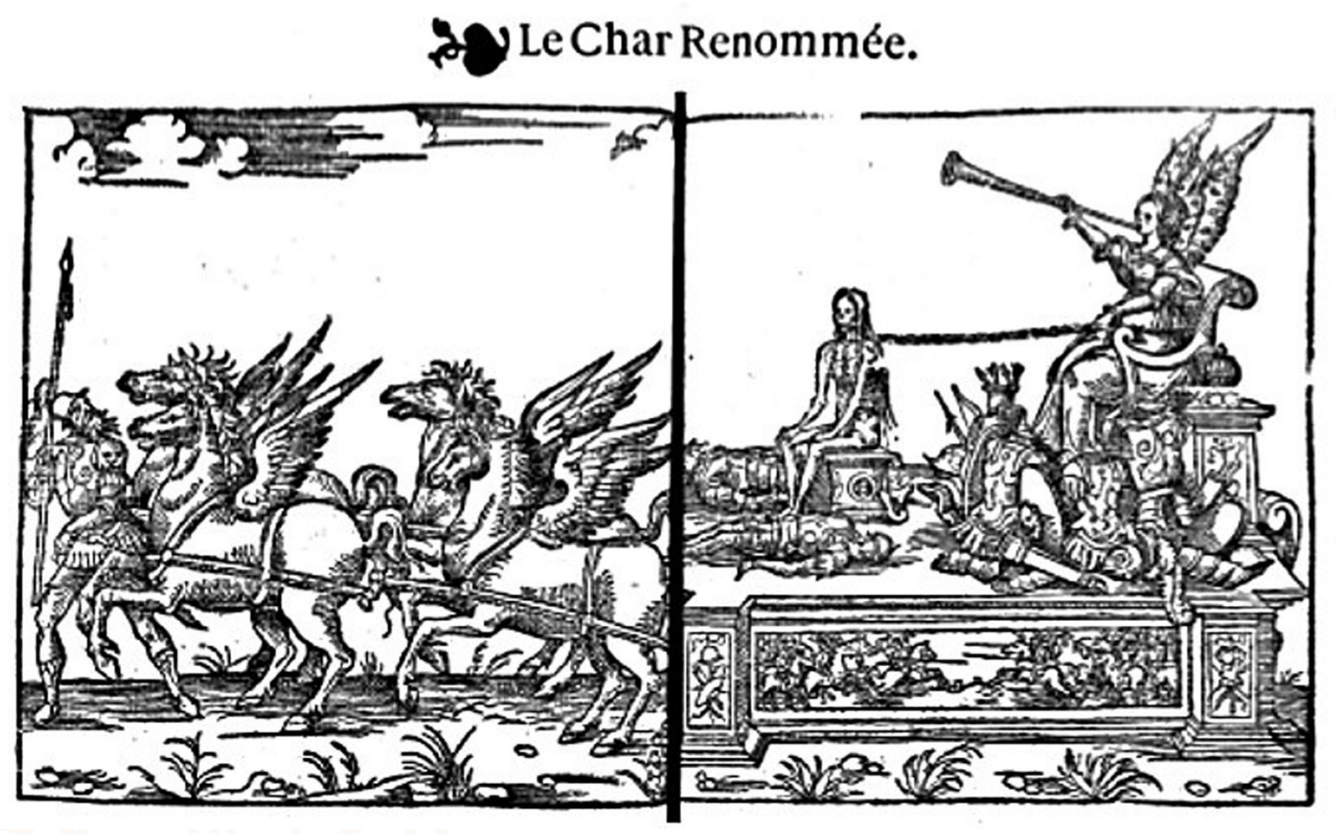

Figura 5 - A Renomada, ou a Celebridade

\section{Les predeceffeurs Roys de France.}

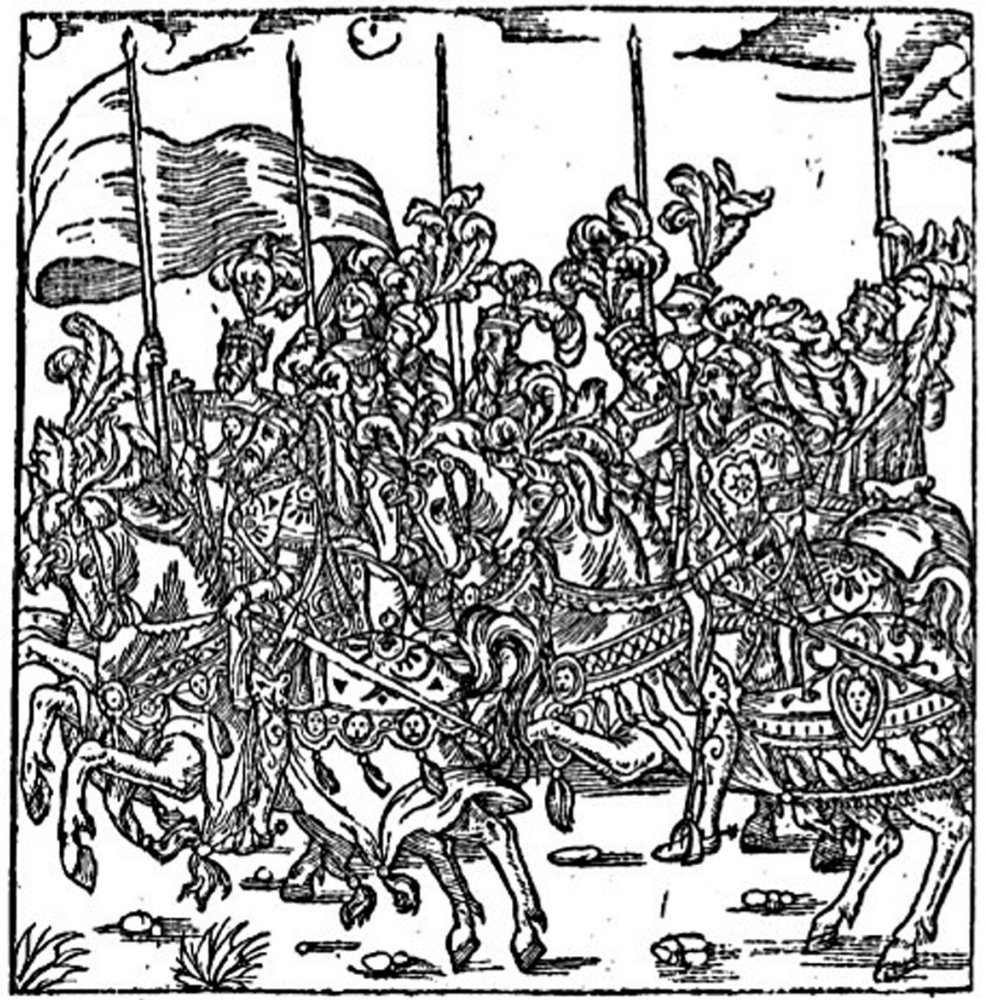

Figura 6 - Homens a cavalo figuram os reis da França 
Quatro cavalos brancos alados puxam este carro triunfal em que uma mulher, também com asas, segura com uma corda um magro ator que representa a Morte. Ele está sentado diante de corpos caídos e despojos de guerra. A Celebridade ou a Renomada é uma alegoria da conquista do rei, mas também da cidade que o saúda pela voz da Dama que recita uma louvação ao soberano: "Rouen, por tua virtude conhecida, sobre a morte te deu, o imortal nome de Rei". Este carro é seguido por 57 homens a cavalo que ruidosamente entram em cena figurando os reis da França do passado, com suas armas e coroas (Figura 6).

O grupo de trompetes que vem em seguida (Figura 7) anuncia a entrada do segundo grande carro triunfal, a alegoria da Religião (Figura 8).

\section{Trompettes.}

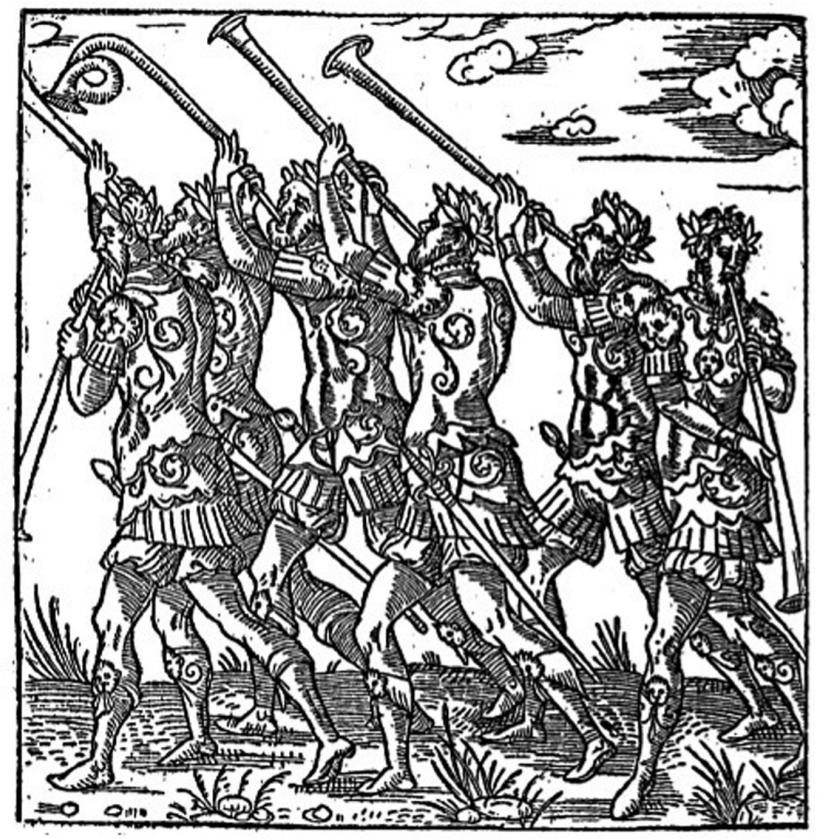

Figura 7 - Trompetes

A composição surge puxada por dois cavalos conduzidos por homens a pé, vestidos com turbantes. Como figura central, está Vesta, deusa com asas. Carregando um templo, ela corporifica a própria Religião. Ao seu lado, a Vitoriosa Virtude, que a contempla no desenho. E, olhando para fora, a Majestade Real. À frente, personificações da Reverência e do Temor. E a pé, fora do carro, um portador da Virgem. Quando o carro para em frente ao rei, o grupo 
canta em coro um poema de louvação. Toda a alegoria ilustra, como nos explica o relato, o esforço dos reis da França em manter a unidade e aumentar o patrimônio da fé católica, contra seus adversários.

I0 Le Charde Religion.

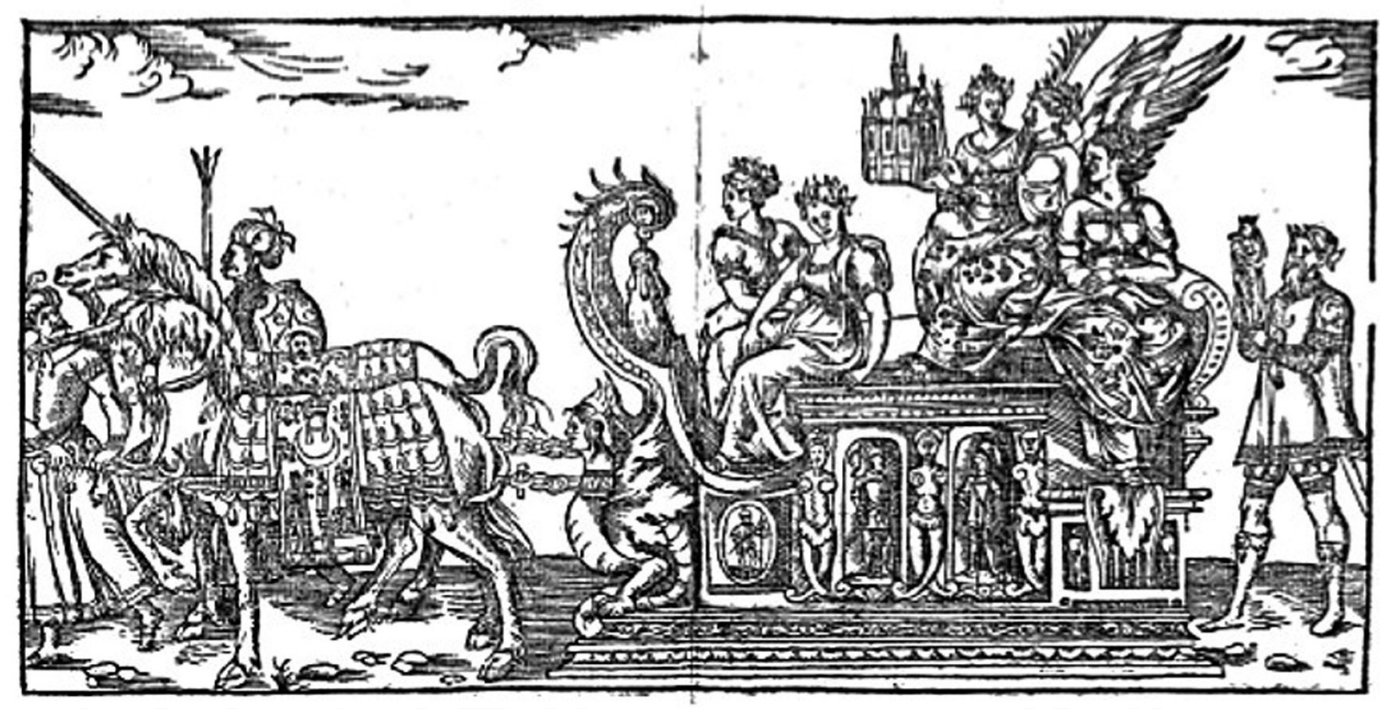

Figura 8 - Religião

La premiere bande.

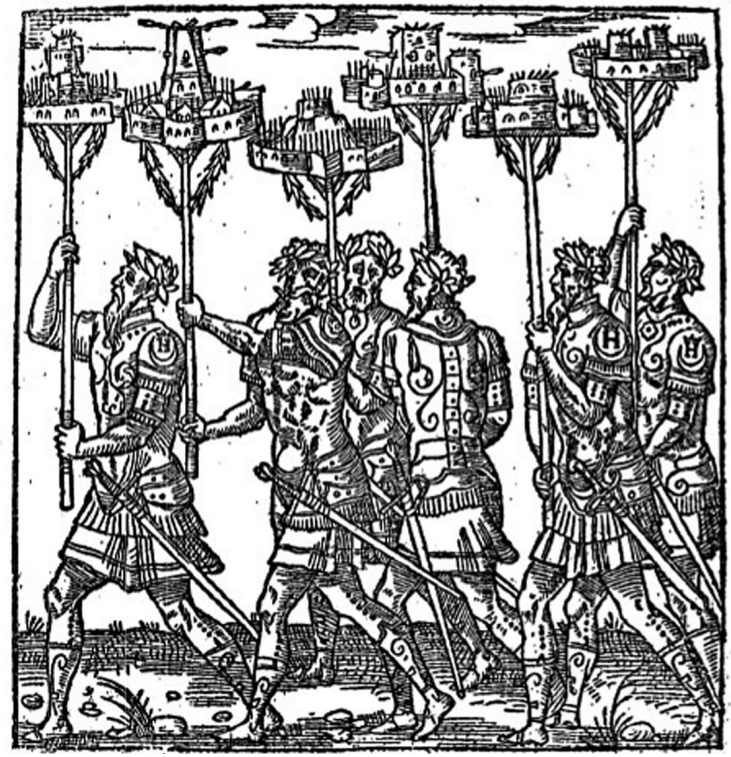

Figura 9 - Portadores das cidades 
O exame de uma festa como essa nos dá elementos para compreender o quanto resquícios desse tipo de imaginário alegórico entrariam por vias tortas na cultura popular brasileira. O que o rei Henrique assiste na sequência é o desfile de seis grupos de portadores de objetos que aludem diretamente à campanha militar de Bolonha-sobre-o-Mar, militares com miniaturas das fortalezas e estandartes com paisagens da região, entremeados pelo imaginário antigo de vasos, coroas de louros e cordeiros vivos (Figuras 9-14).

La feconde bande.

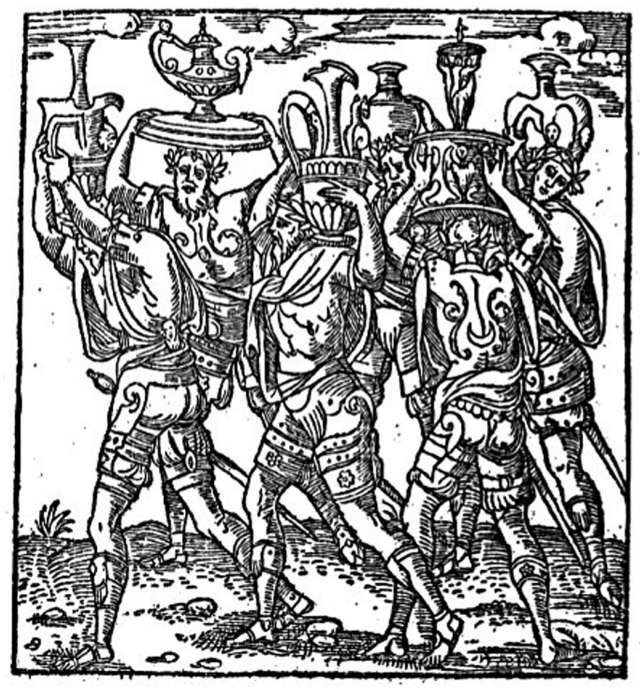

Figura 10 - Portadores dos troféus

La tierce bande.

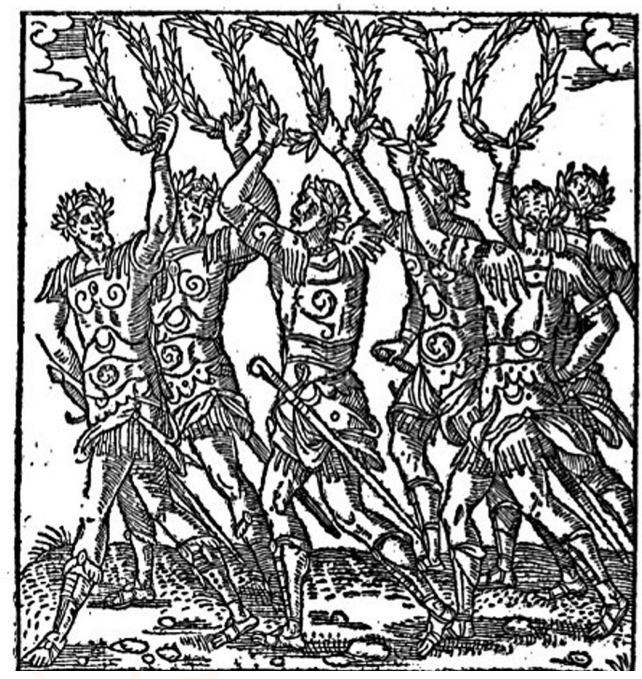

Figura 11 - Portadores da coroa de louros 
La quarte bande.

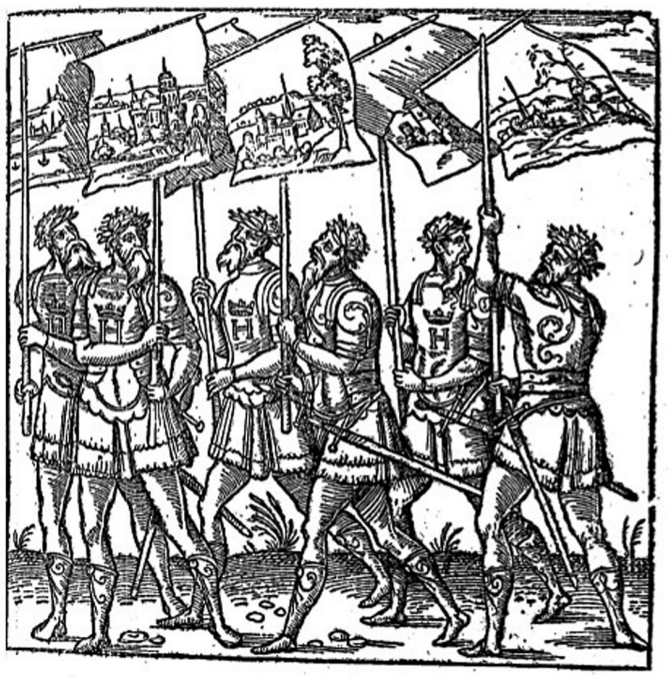

Figura 12 - Portadores de estandartes

La cinqiefme bande.

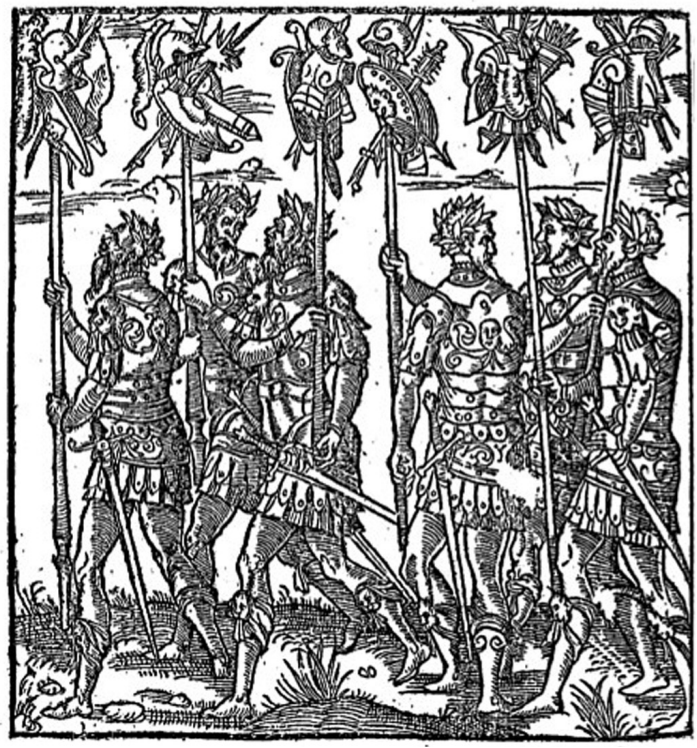

Figura 13 - Portadores das armas dos derrotados 


\section{La fixiefme bande.}

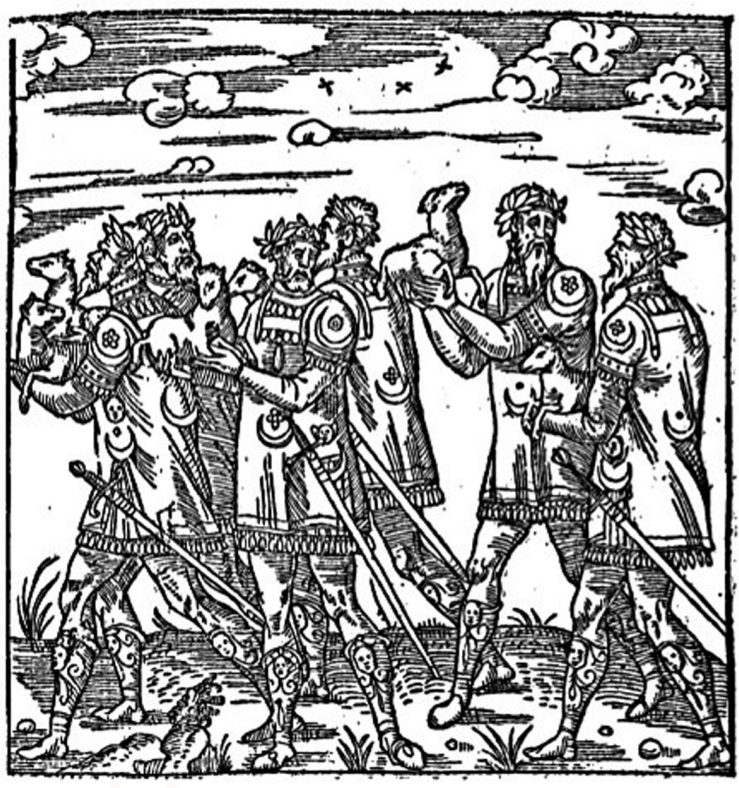

Figura 14 - Portadores dos cordeiros

O desfile desses seis pelotões é fechado por uma tropa de cinquenta soldados a pé (Figura 15).

La figure des Soldatz.

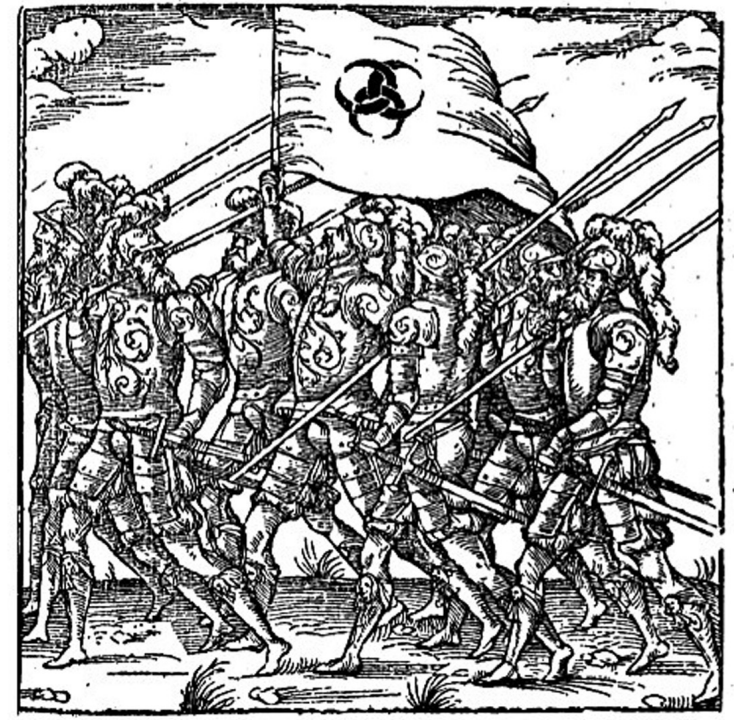

Figura 15 - Guerreiros da França 
Pode-se se dizer que essa primeira parte da festa, quando o rei ainda está no palanque, se encaminha para seu desfecho quando aparecem dois grupos de figuras de elefantes. São provavelmente mulas disfarçadas, vestidas com cabeças de elefantes, muito semelhantes aos originais, segundo informa o relato (Figuras 16 e 17).

La premiere figure des Elephantz.

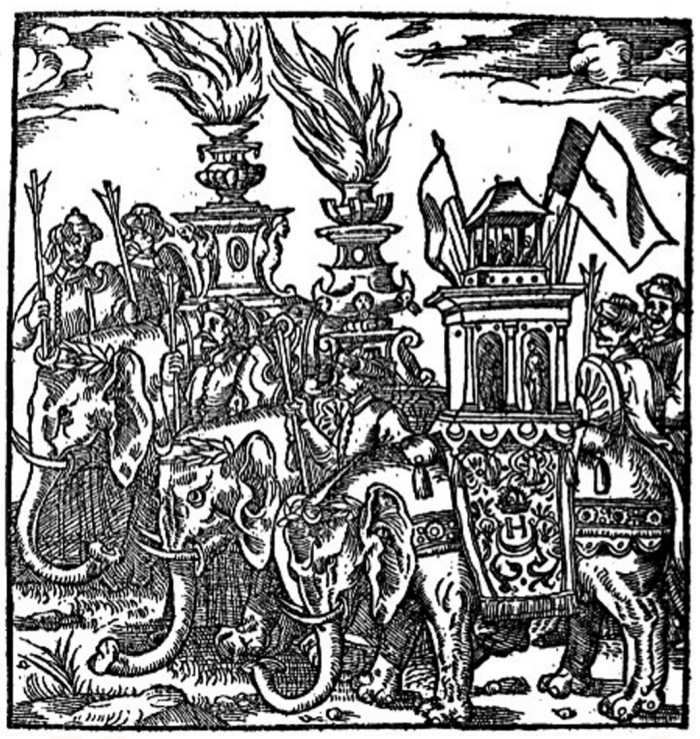

Figura 16 - Desfile dos elefantes

\section{La feconde figure des Elephantz.}

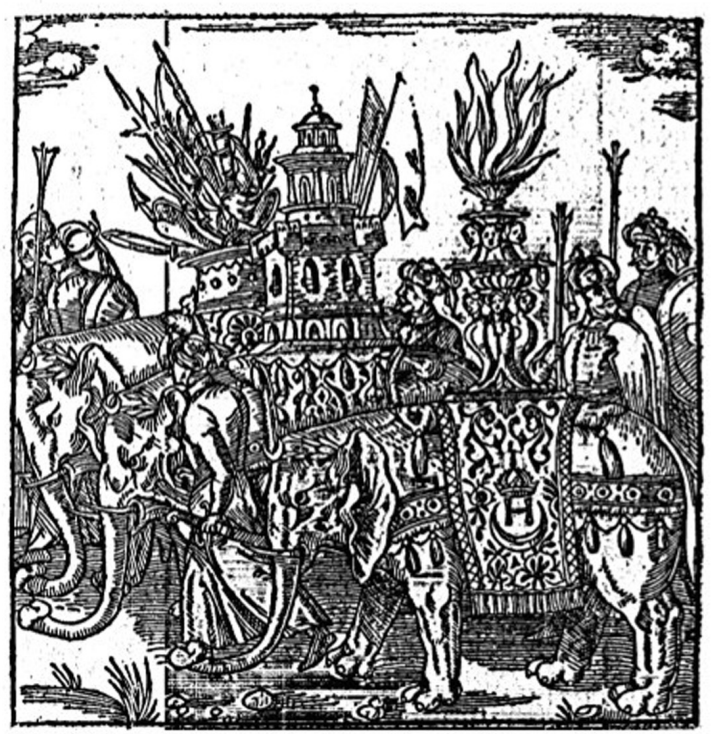

Figura 17 - Segundo grupo de elefantes 
Esses pseudoelefantes trazem nas costas miniaturas de templos e vasos com fogo, seguidos da tradicional imagem dos cativos, de ninfas e do último carro triunfal, o da Fortuna.

Como sabiam os encenadores franceses, o Triunfo de Henrique II deveria ser um comentário ao presente e uma imitação dos triunfadores da Antiguidade. Mas quais as razões desse anacronismo algo deliberado, que cria o efeito de uma formação fora do tempo e do lugar?

Temos a sorte de dispor de outra fonte documental que nos permite ampliar as imagens sobre o espetáculo: um manuscrito produzido antes da versão impressa. Neste documento raro há ilustrações coloridas, feitas com alguma liberdade criativa pelo artista anônimo que dispõe no mesmo quadro alegorias que surgiram no desfile separadamente: anjos bíblicos, elefantes, cavaleiros medievais, heráldica nobiliárquica, dinâmica triunfal militarizada (Figuras 18 e 19).

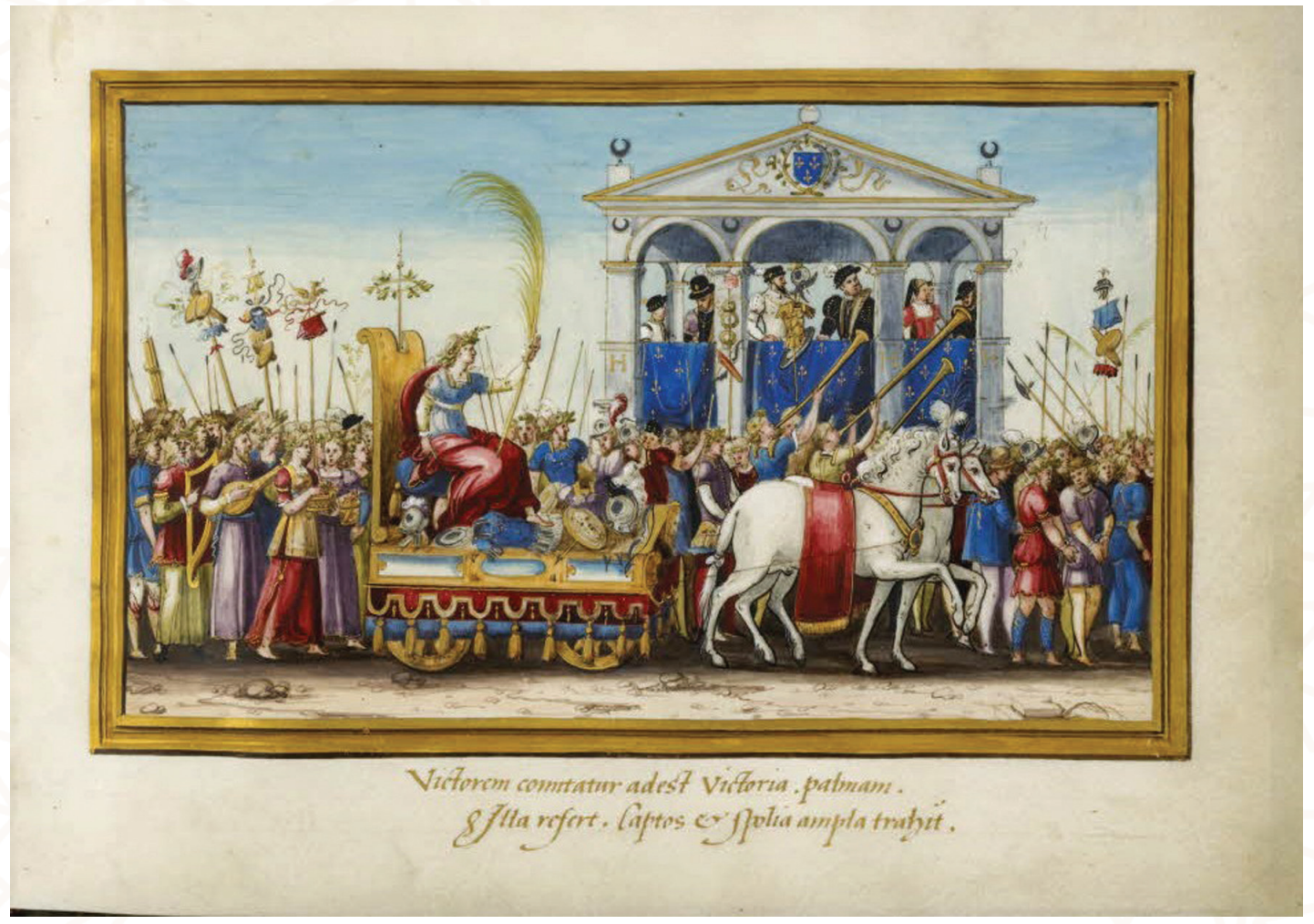

Figura 18 - Carro da Renomada, a alegoria da Vitória, na imagem do manuscrito 


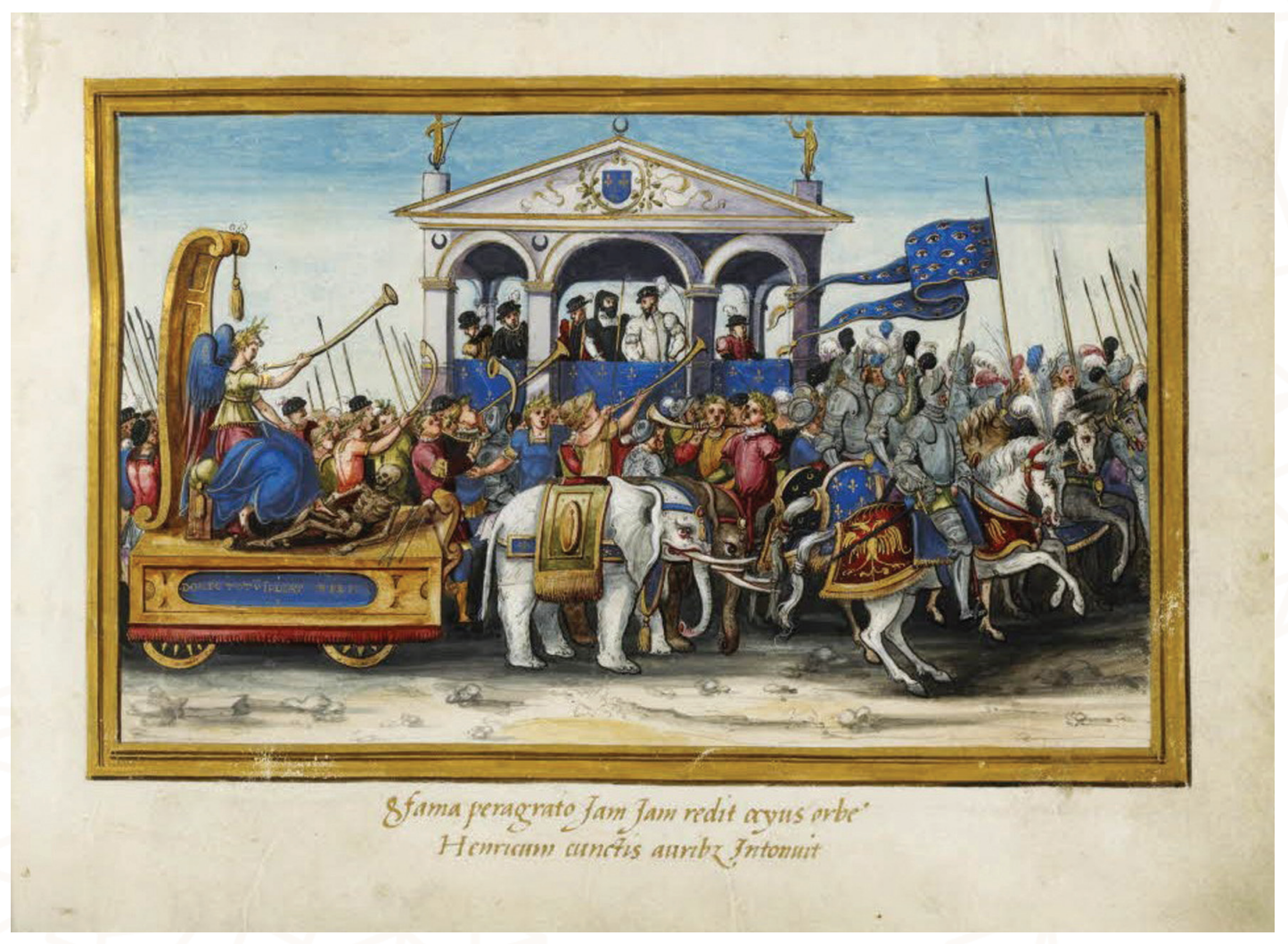

Figura 19 - Carro da Fama na imagem do manuscrito

Como já mencionado, essa modalidade de cerimônia, que àquele tempo se estabelecia como gênero - o Triunfo -, teve sua origem longínqua nos ritos gregos de agradecimento aos deuses pelas vitórias nas guerras, tal como descritos numa peça como Sete contra Tebas, de Ésquilo. Eram cortejos para o pagamento de promessas, feitos com o sacrifício de animais, ovelhas e touros, e a deposição dos troféus - obtidos nas campanhas militares - nos altares dos deuses ${ }^{5}$.

5 "Depois de cada vitória, oferecia-se o sacrifício; daqui a origem do triunfo tão conhecido entre os romanos, e que não o era menos entre os gregos. Este costume surgiu como consequência daquela opinião atribuidora de vitória aos deuses da cidade. Antes da batalha, o exército dirigia-lhe oração análoga à que se encontra em Ésquilo: 'A vós, deuses que habitais e possuís o nosso território, se as nossas armas forem felizes e a nossa urbe salva, eu vos prometo regar os vossos altares com o sangue das ovelhas, imolar-vos touros e depor nos vossos santos templos os troféus conquistados com a lança'. Em virtude deste prometimento, o vencedor ficava de dívida em aberto para ofertar um sacrifício. $\mathrm{O}$ exército reentrava na urbe para cumpri-lo: dirigia-se para o templo, formando longa procissão e cantando o hino sagrado: $\theta$ pía $\mu \beta 0 \varsigma$ (triunfo). Em Roma, a cerimônia era quase a mesma. [...] É certo, mais tarde, os soldados não se tomarem de grandes escrúpulos e haverem substituído o hino por canções de caserna ou zombarias contra seu próprio general. Mas guardaram pelo o costume de repetir, de vez em quando, o antigo estribilho: 
Ainda que a historiografia seja imprecisa quanto a esse ponto, houve a tendência, ao longo do século XV, de que as formas das entradas reais, sob a influência dos círculos da nobreza palaciana culta (a chamada noblesse de robe), fossem associadas às procissões triunfais romanas, e a própria organização das festas se modelasse pelas descrições da literatura clássica. Se procurarmos em fontes como Suetônio (1951, p. 29), por exemplo, em Vida de César, verificamos que as célebres palavras "Veni, vidi, vici" (Vim, vi, venci) após uma campanha vitoriosa, aparecem como uma inscrição feita num carro triunfal romano. E é dessa narrativa sobre César que deve ter surgido o costume da procissão de elefantes que encontramos ainda na festa de Rouen.

Nos escritos de Plutarco (1830) sobre a vida de Paulo Emílio (Aemilius Paulus), no episódio de sua questionada vitória sobre os macedônios, em que aprisionou o rei inimigo, enfim se decidindo pela homenagem de um triunfo público, encontra-se uma boa descrição da cerimônia triunfal, em meio à qual há referência aos palcos espalhados pela cidade, ao grupo de trompetistas e ao empilhamento de pedaços das armaduras, capacetes e armas inimigas sobre os carros, além do controverso grupo de prisioneiros: os nobres cativos "derramando lágrimas e esticando as mãos para os espectadores" que reaparece em Rouen ${ }^{6}$.

lo triumphe! $E$ foi justamente este refrão sagrado que deu seu nome à cerimônia" (COULANGES, 1971, p. 203-204).

6 "Después a Emilio fue decretado el triunfo. Ordenóse luego, segun la memoria que ha quedado, de esta manera: el pueblo, habiéndose levantado tablados en los teatros para las carreras de los caballos que se llaman circos, y en las inmediaciones de la plaza, y en todos los parages por donde habia de pasar la pompa, la vió desde ellos, yendo toda la gente vestida muy de limpio; los templos todos estaban abiertos y llenos de coronas y perfumes; muchos alguaciles y maceros, apartando á los que in discretamente corrian y se ponian en medio, dejaban libre y desembarazada carrera. La ceremonia toda se repartió en tres dias [...] En el dia tercero, muy de mañana, abrieron la pompa trompeteros, que tocaban, no una marcha compasada y propia del caso, sino aquella con que se incitan los Romanos á sí mismos en medio de la batalla; y en seguida eran conducidos ciento veinte bueyes cebones, á los que se les habian dorado los cuernos, y que habian sido adornados con cintas y coronas. Los jóvenes que los llevaban, ceñidos con fajas muy vistosas, los guiaban al sacrificio, y con ellos otros mas mocitos con jarros de plata oro para las libaciones. Venian luego los que conducian la moneda de oro, repartida en esportillas de á tres talentos como la de plata, y estas eran al todo setenta e siete. Tras estos seguian los que conducian el ánfora sagrada, que Emilio habia hecho guarnecer con pedrería de hasta diez talentes, y los que iban ense ñando las Antigonidas, las Selencidas, los Tericleos y toda la bajilla de que usaba Perseo en sus banquetes. En pos iba el carro de Perseo y sus armas, y la diadema puesta sobre las armas. Despues con algun intervalo eran conducidos como esclavos los hijos del Rey, y con ellos una turba de camareros, de maestros y de ayos, bañados en lágrimas, y que ten dian las manos á los espectadores, adiestrando 
Quando, por volta de 1486, o pintor Andrea Mantegna produz seus nove grandes painéis renascentistas sobre o Triunfo de César (também pintados para um espetáculo teatral público), ele fixa uma tradição pictórica anterior que corresponde ao desenvolvimento de uma modalidade de encenação triunfal que ainda duraria muito tempo, e chegaria, em versões variadas, à colônia do Brasil. Os painéis de Mantegna são reveladores quanto a sua modelagem literária (Figuras 20-22).

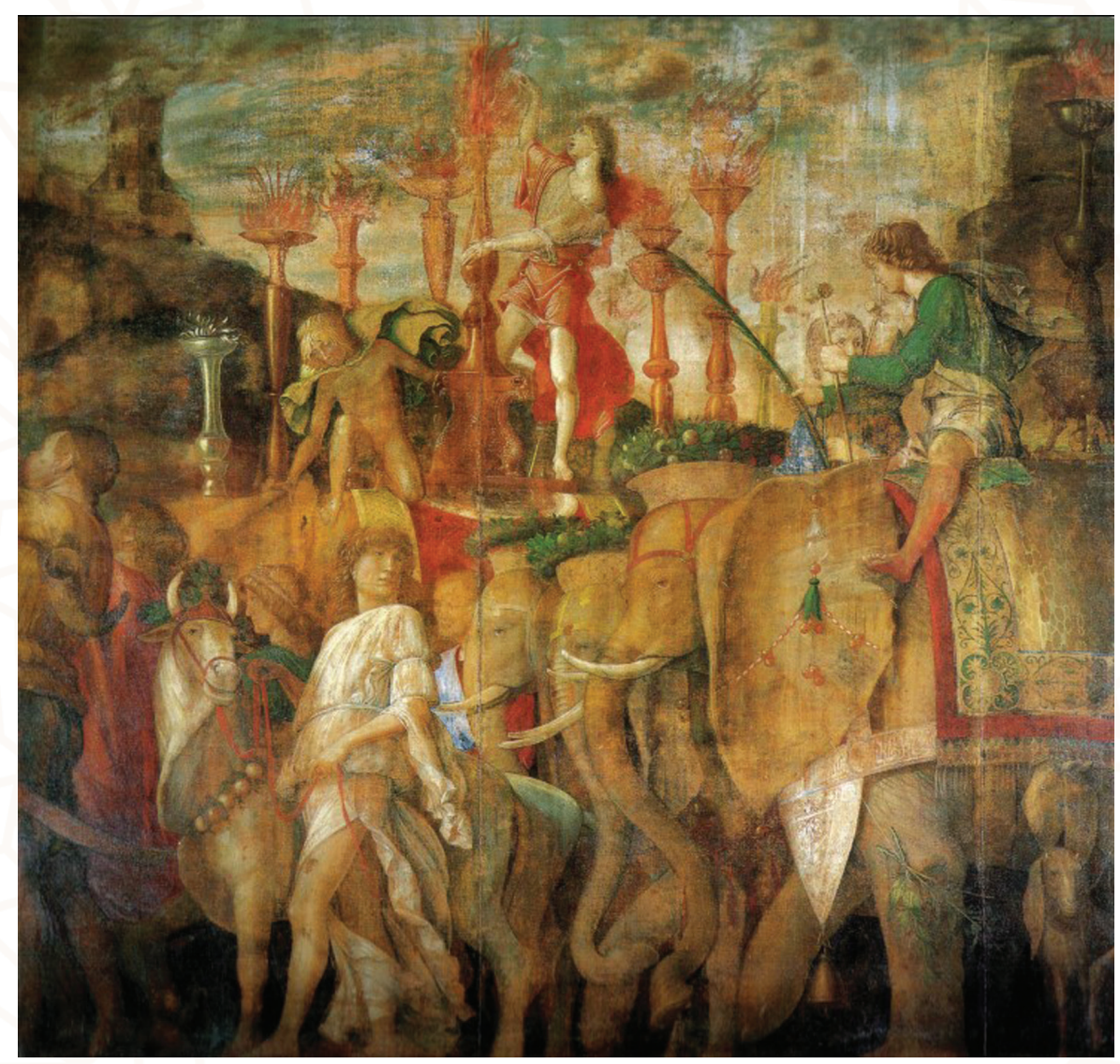

Figura 20 - O desfile dos elefantes em Triunfos de César, de Andrea Mantegna

á los niños á pedir y suplicar. Eran estos dos varones y una hembra, poco atentos á la magnitud de sus desgracias á causa de la edad; y por lo mismo esta simplicidad suya en semejante mudanza los hacia mas dignos de compasion; de manera que estuvo en muy poco el que Perseo se les pasase sin ser visto: tan fija tenian los Romanos la vista por compasion sobre aquellos inocentes á muchos les sucedió caérseles las lágrimas; y entre todos no hubo ninguno para quien en aquel espectáculo no estuviese mezclado el pesar con el gozo hasta que los niños hubieron passado." (PLUTARCO, 1830, p. 175-180). 


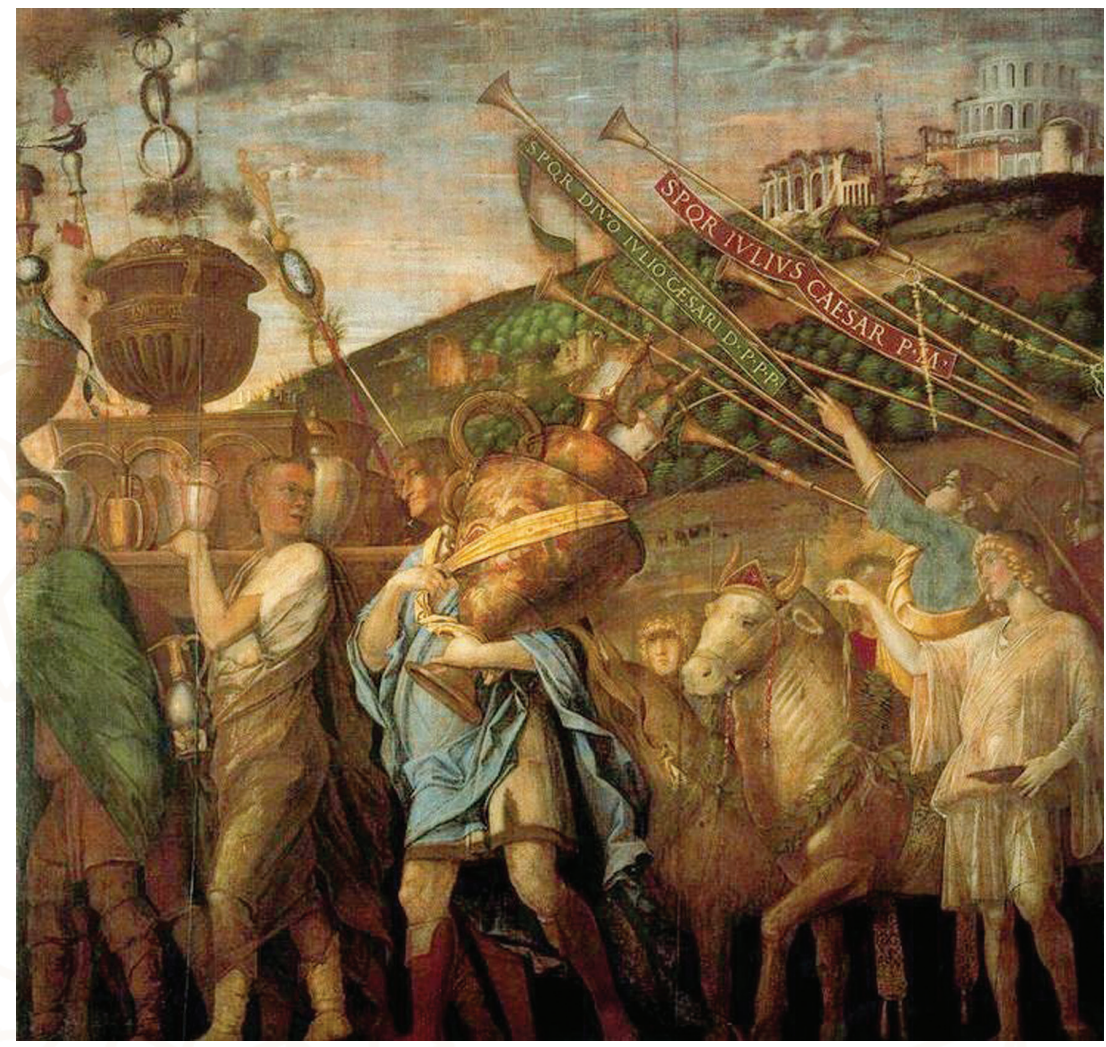

Figura 21 - Portadores de vasos em Triunfos de César, de Andrea Mantegna

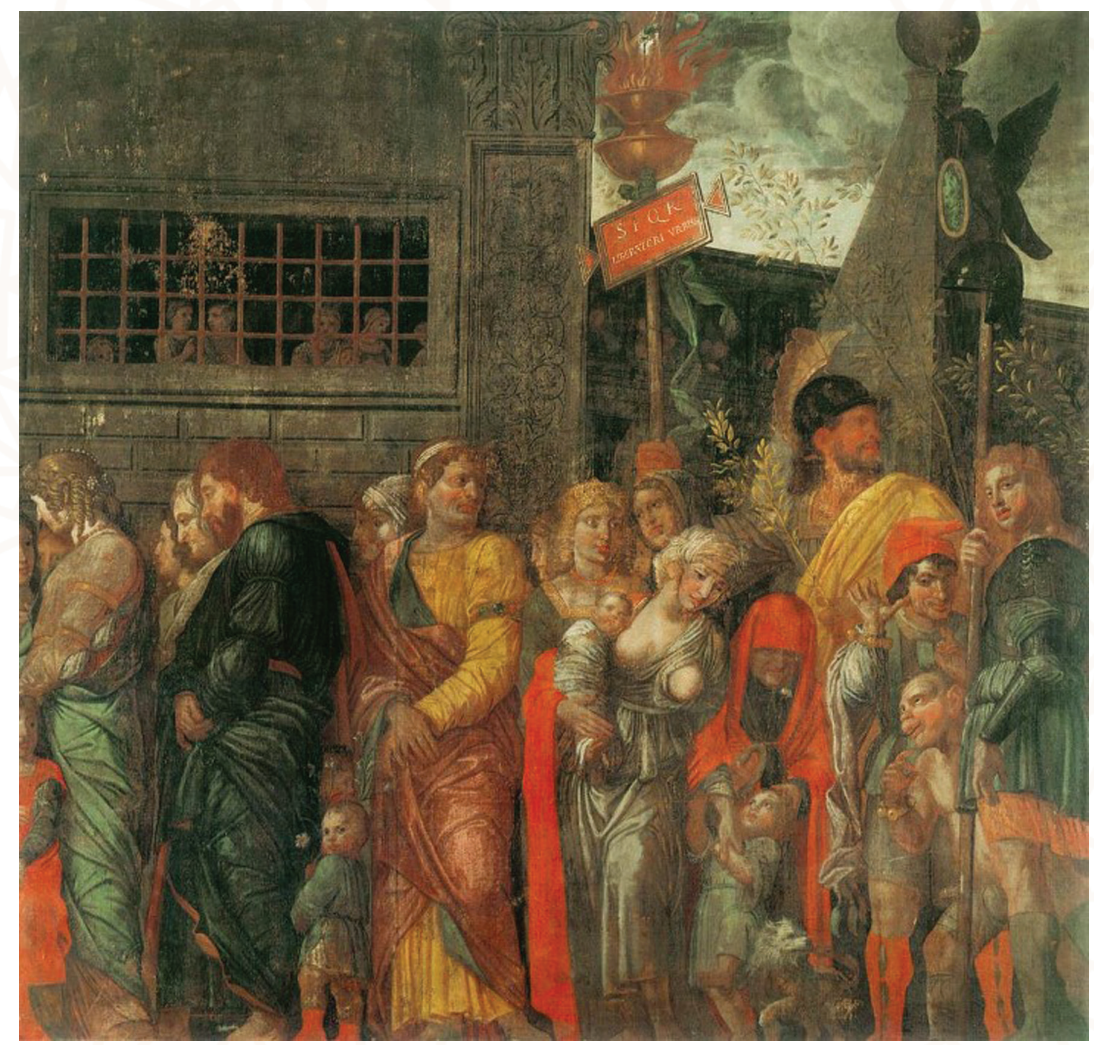

Figura 22 - Cativos em Triunfos de César, de Andrea Mantegna 
O último dos carros triunfais de Rouen, que imita a tradição da coroa de louros sendo posta na cabeça de César, apresenta a Fortuna que anuncia o coroamento do rei Henrique. O próprio desfile é assim coroado, organizando-se a partir daí como procissão "total", quando o rei espectador se incorpora ao desfile. Postas em paralelo, as imagens nos permitem observar o vínculo entre a encenação quinhentista e o tópico classicizante cristalizado em Mantegna, numa adaptação de formas antigas que alude aos desejos de legitimação do tempo (Figuras 23-25).

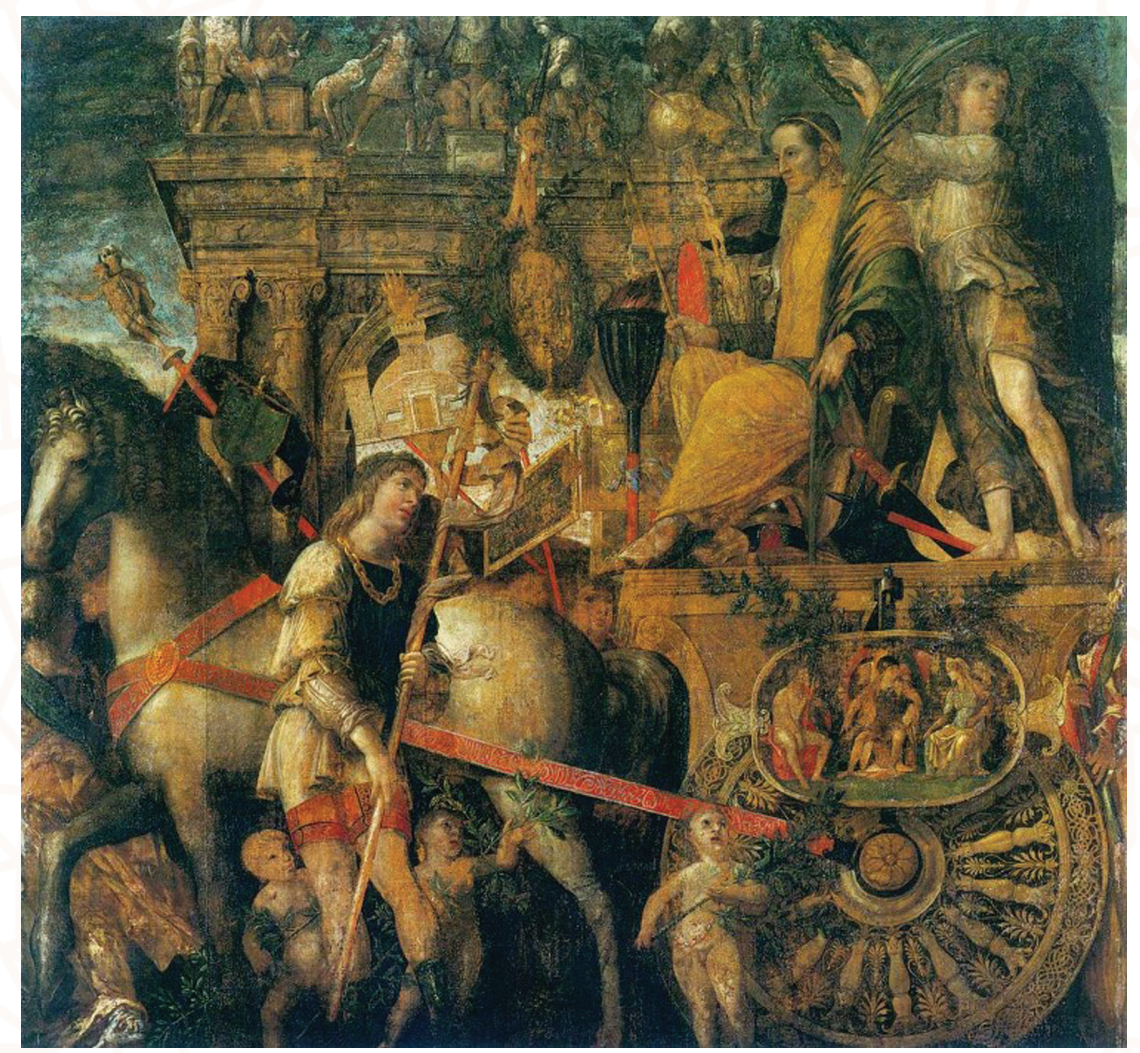

Figura 23 - Louros da vitória, em Triunfos de César, de Andrea Mantegna

Mas em que momento desse espetáculo quinhentista poderiam surgir os tupinambás do Brasil? E qual seria sua função nessa cena que se deslocará somente após o rei do palanque contemplar sua própria imagem no rei do teatro. (E o mesmo espelhismo se dá com a posterior entrada do jovem ator que representa o delfim François, futuro rei, que entra solitariamente a cavalo e encara seu duplo na plateia, sendo logo seguido por cinquenta cavaleiros militares.) É significativo que os atores peçam desculpas (em versos) pela indignidade dessa tentativa de representação. 


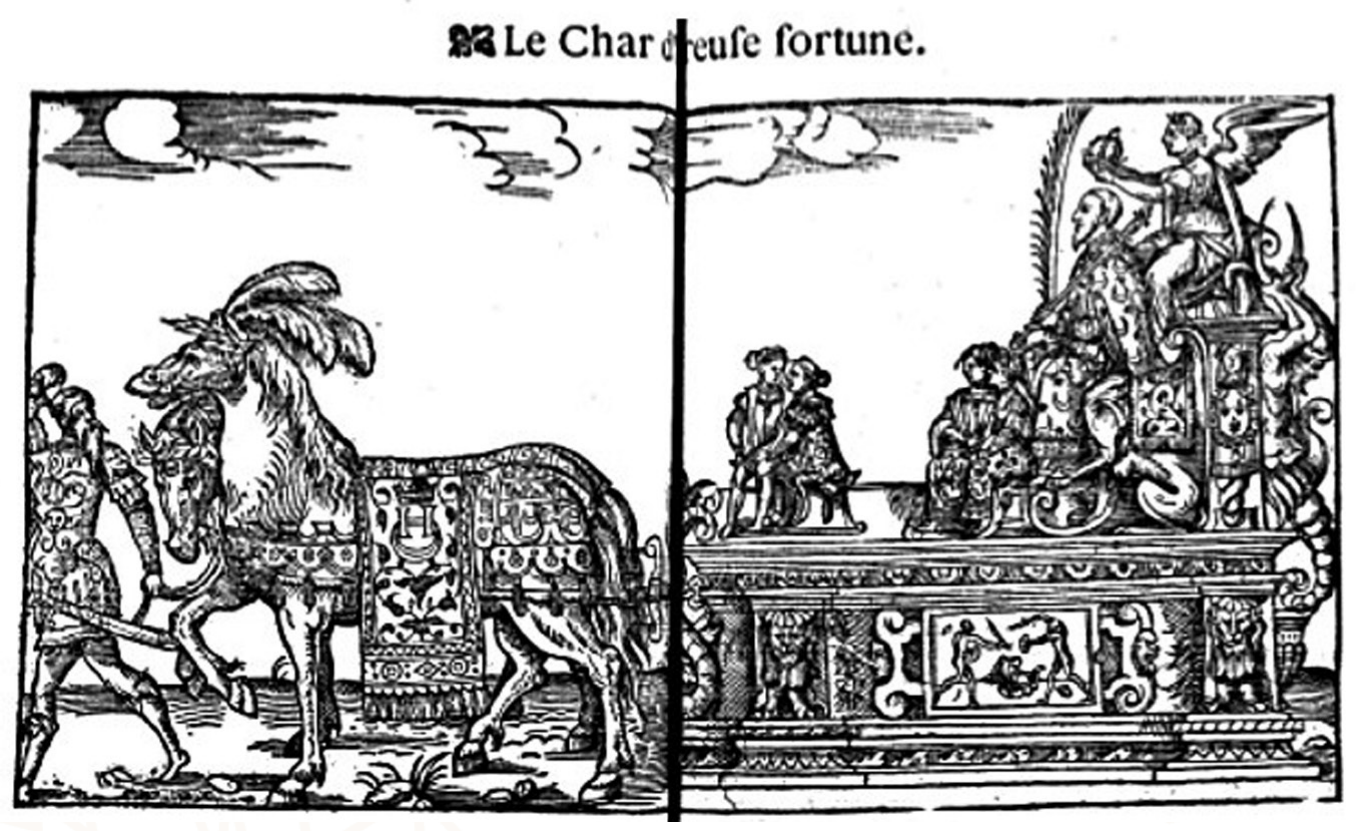

Figura 24 - A coroação de Henrique na versão impressa, modelada pela tradição dos louros

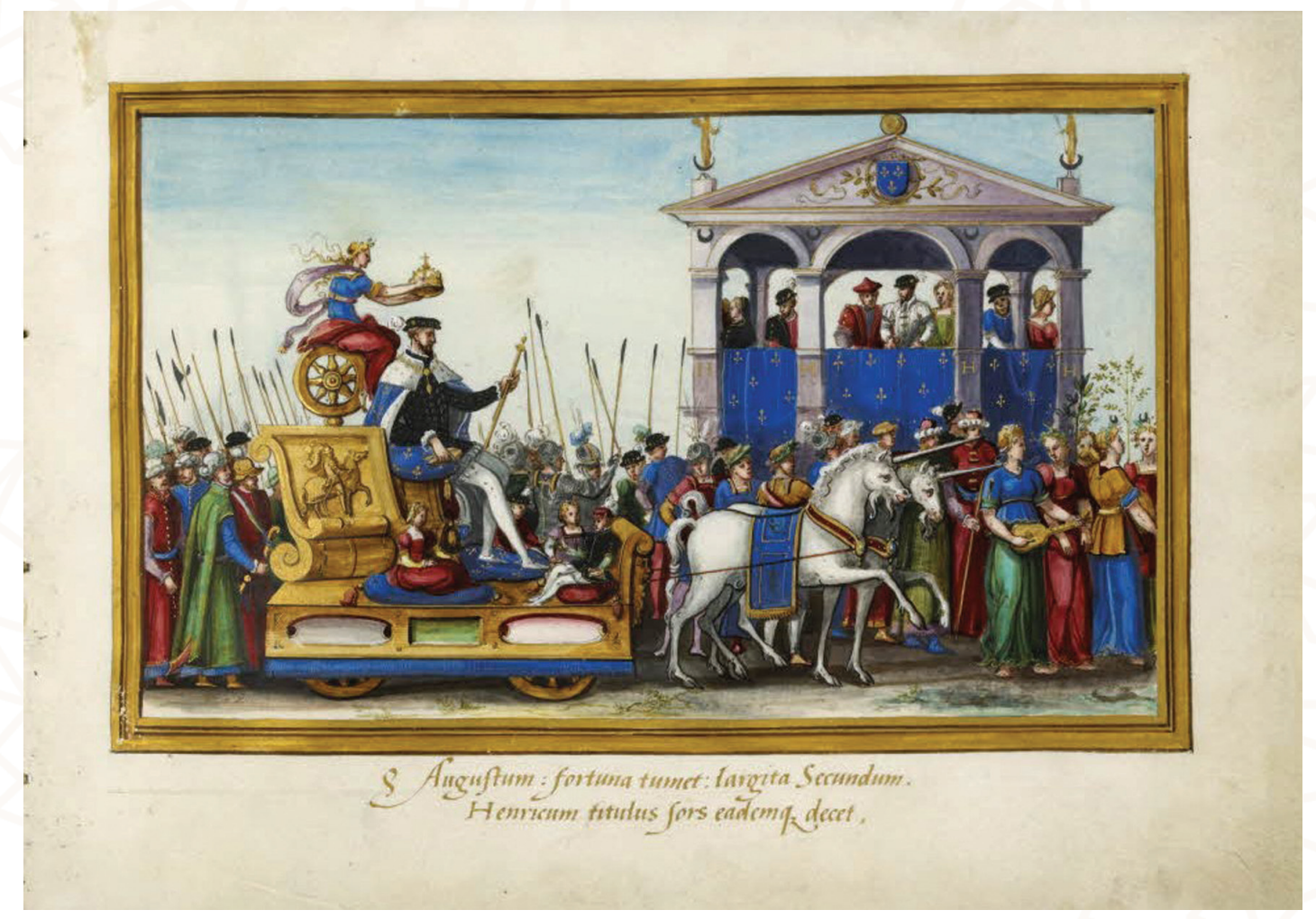

Figura 25 - A coroação de Henrique na versão manuscrita 
Os movimentos cênicos que se organizam a partir daí configuram a nova fase, em que aquela sociedade urbana, hierarquicamente disposta, faz a entrada junto ao rei e ocupa a cidade. E o ponto de vista do espectador soberano, o rei, torna-se móvel. O capitão militar da cidade surge a pé como que a indicar que todos devem atravessar a ponte. Religiosos, nobres militares e trezentos burgueses a pé, nomeados segundos suas profissões, abrem alas para que o rei e seu séquito possam enfim dirigir-se do arrabalde à ponte (Figuras 26 e 27).

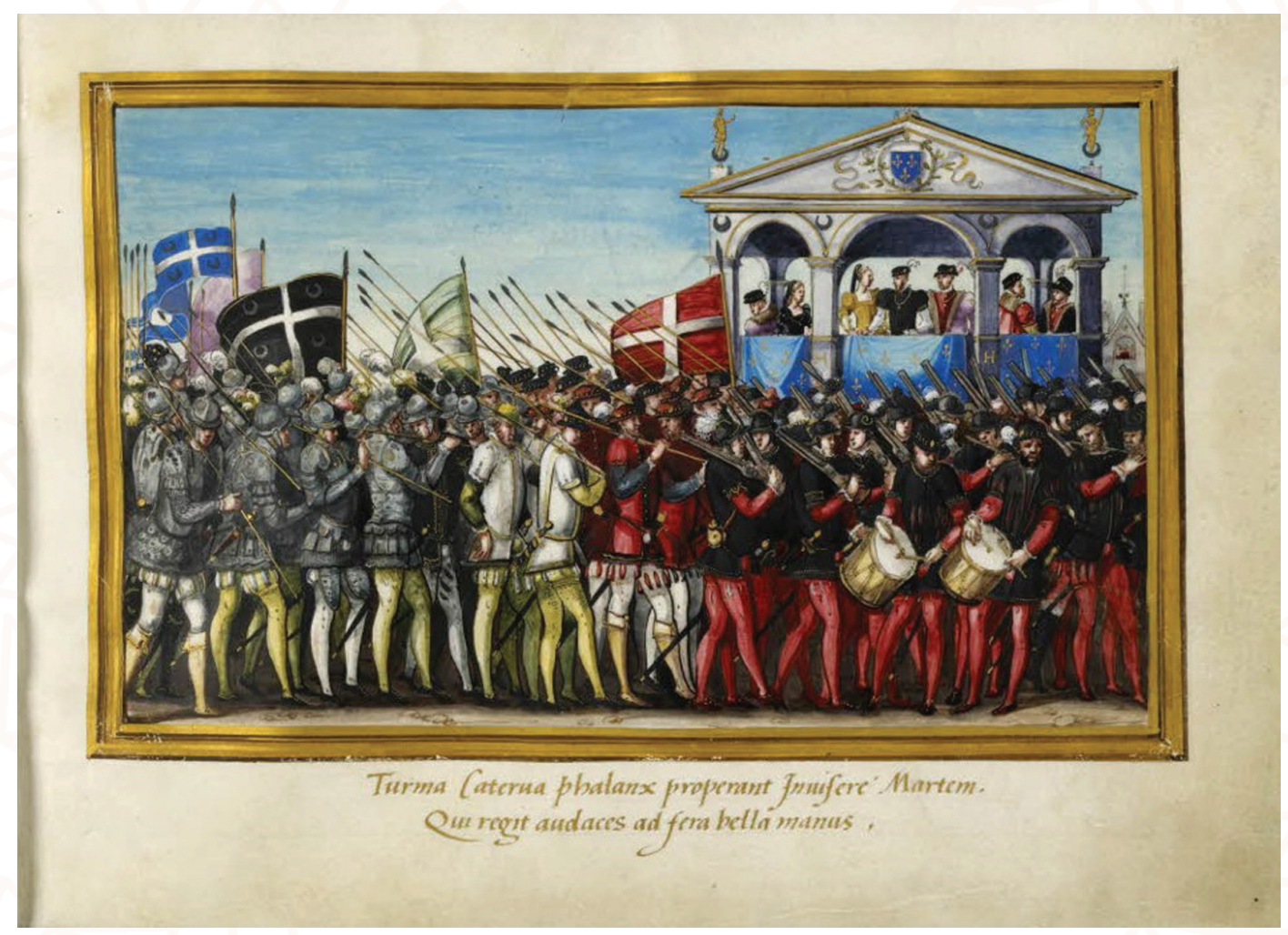

Figura 26 - Imagem dos agrupamentos militares na versão manuscrita

É neste momento, ao aproximar-se do Sena e atravessar outro arco do triunfo, edificado como ruína algo apocalíptica, que Henrique II, agora incorporado à procissão, assiste aos grandes espetáculos organizados para ele junto às margens, podendo contemplá-los durante toda a demorada travessia da ponte. São cenas que culminam em batalhas. 


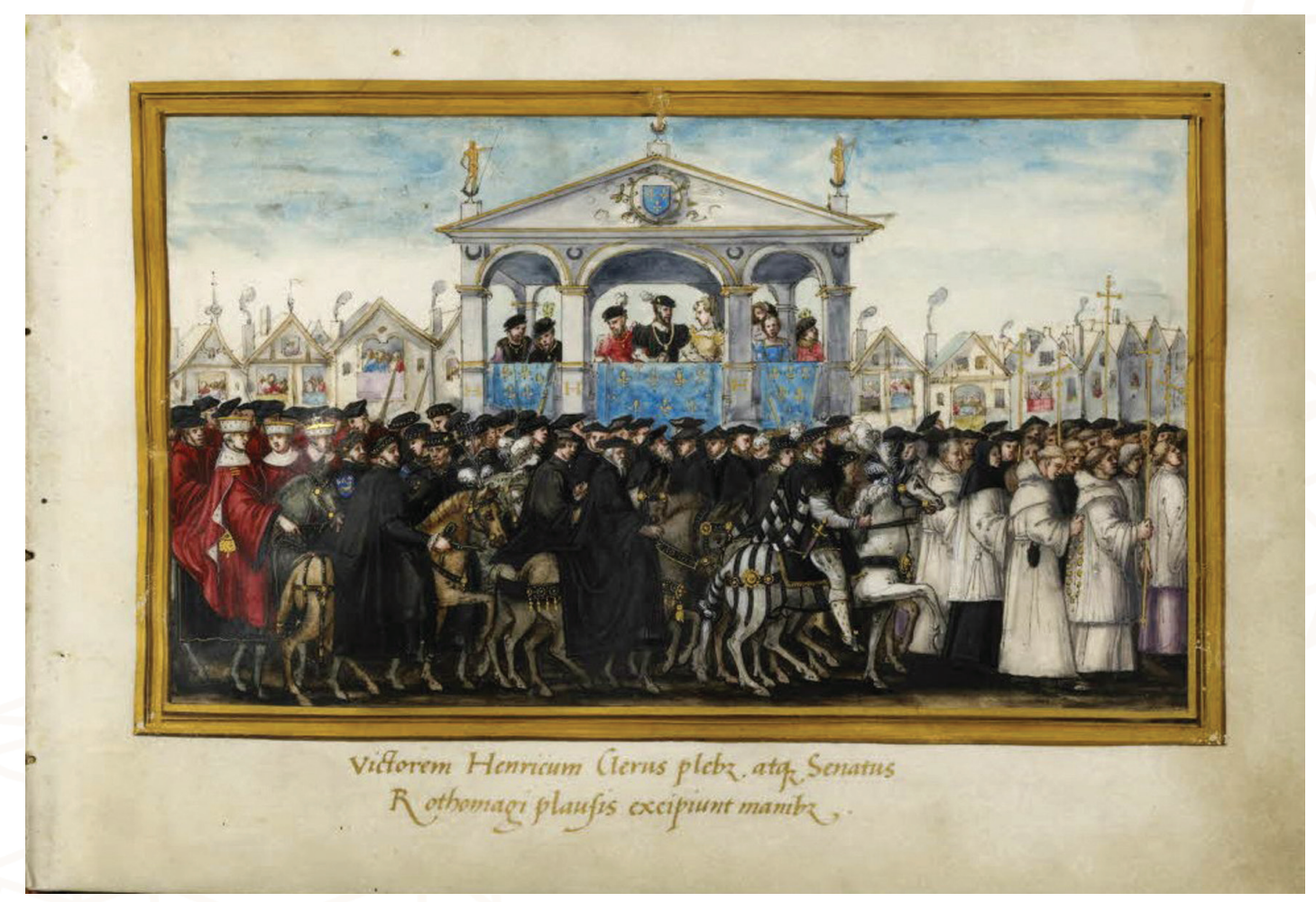

Figura 27 - Grupos da elite da cidade na versão manuscrita

A primeira delas ocorre num grande terreno, próximo à margem. É o espetáculo dos tupinambás do Brasil: trezentos atores em meio a uma floresta reconstruída, sendo que cinquenta deles eram índios que vieram do Brasil para a ocasião, provavelmente oriundos de grupos da região da Bahia, a julgar pela alusão a seus inimigos tabajaras.

O que motivaria esse espetáculo, essa teatralização da vida indígena conectada ao imaginário da monarquia cristã e da Antiguidade greco-latina? A razão mais evidente tem relações diretas com o enriquecimento da cidade de Rouen. Desde 1504 os marinheiros da Normandia mantinham contato regular com os tupinambás, um dos principais grupos da costa brasileira no século XVI. Há décadas, portanto, havia um comércio regular em que os índios cortavam e preparavam os troncos de pau-brasil que serviam à crescente produção de tecidos coloridos que se abastecia nos mercados da região. Como o processo era demorado, muitos marinheiros normandos viviam entre os tupinambás durante os meses em que preparavam a mercadoria para o embarque. Dominavam assim a língua, conheciam esposas índias e recebiam até nomes tupis. $\mathrm{O}$ ódio do mercenário alemão Hans Staden a um desses 
franceses, que já não se compadecia diante da possibilidade de que um cristão fosse devorado pelos índios, testemunha essa intimidade adquirida.

Esta participação no espetáculo de Rouen, portanto, se baseava num vínculo social gerado pela troca que tinha vínculos diretos com o crescimento econômico da região de comerciantes navegadores. O que nos interessa, contudo, é pensar nos sentidos (e ambivalências) possíveis dessa relação entre formas e temas. $O$ gravurista da relação impressa apresenta uma imagem do conjunto tupinambá dentro da festa (Figura 28).

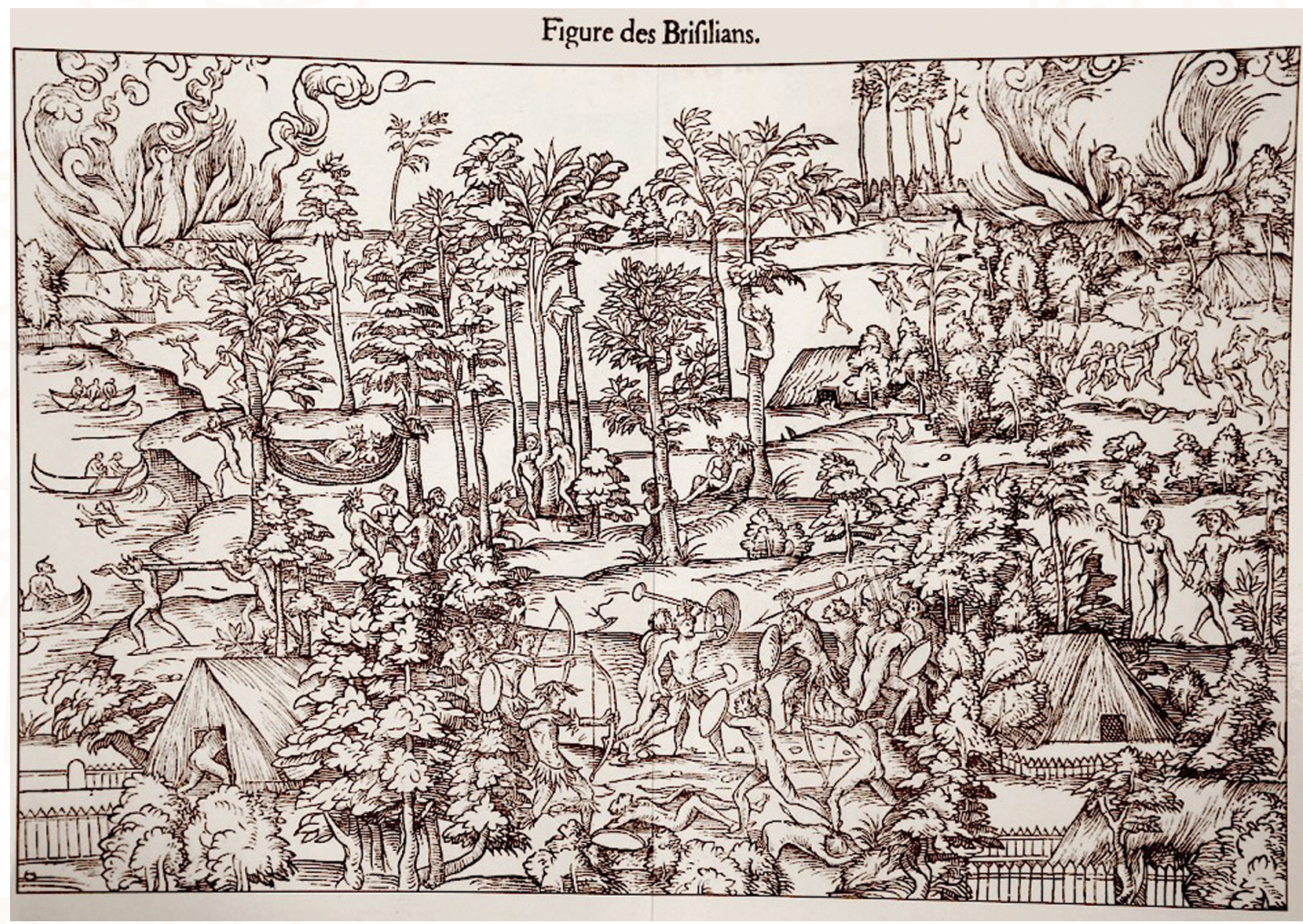

Figura 28 - Imagem dos brasileiros na versão impressa

O grande terreno à beira do Sena foi preenchido com dezenas de árvores que imitavam a mata do Brasil. Troncos foram pintados de vermelho. Folhas e galhos dos trópicos foram sobrepostos às árvores europeias, transplantadas para o espetáculo. Casas que imitavam as grandes ocas coletivas onde viviam os tupinambás foram edificadas. Todos estavam nus, como enfatiza o autor do relato, mesmo os franceses, com os corpos vermelhos de urucum. E grande parte dos 250 atores-marinheiros (e algumas mulheres) se dispuseram a também furar as orelhas ou os lábios inferiores para pendurar 
pedras verdes e brancas, à maneira tupinambá. Alguns simulavam dançar. Outros dormiam em redes ou caçavam macacos e papagaios importados para o evento. Aqueles que estavam mais próximos à água cortavam toras de madeira e simulavam o preparo do pau-brasil.

Todo o processo comercial foi encenado: a permuta da madeira por machados e foice, e seu embarque, feito por canoas, num navio francês, ricamente decorado e ali estacionado. $\mathrm{O}$ auge desse espetáculo estava na representação de um combate desencadeado pela aproximação de uma suposta tribo inimiga, os tabajaras. O chefe do grupo guerreiro invasor, um morubixaba (ou morbicha, na transcrição equivocada do relato) incita o grupo ao combate, em língua brasílica, com gestos apaixonados. A luta simulada acontece com porretes, arcos e flechas e com o tacape tradicional (o ibirapema tupinambá, usado para matar o inimigo com um golpe na cabeça). A cena do violento combate termina com a fuga dos tabajaras e o incêndio de sua casa.

A encenação tupinambá logo é complementada por um outro espetáculo cheio de fogos de artifícios: uma tradicional naumaquia, uma batalha aquática que tem início quando os navios franceses que comerciam com os índios são atacados por uma caravela portuguesa. Esse segundo combate, do qual também participam os índios, culmina igualmente em fogo: a nau portuguesa é incendiada pela artilharia francesa, sendo que o realismo pirotécnico da cena não recusa a participação de tritões e figuras mitológicas do mar. Lembremos que o próprio embaixador de Portugal estava presente à festa, em meio aos corpos diplomáticos de várias nações, e assistiu a essa imagem da disputa ainda não declarada entre portugueses e franceses em relação ao litoral brasileiro.

Há uma bela imagem da versão manuscrita em que se tem uma visão geral da procissão e dos espetáculos, com alguma liberdade criativa do gravurista na medida em que os espaços reais são adulterados. Uma imagem colorida da naumaquia, talvez feita a partir da versão impressa, nos ajuda a visualizar a modalidade de combate teatral sobre as águas (Figuras 29 e 30).

O autor do relato de Rouen, ao descrever a cena tupinambá, faz uso de uma palavra grega curiosa para nomear o espetáculo encenado por esse grande grupo de atores de corpos nus, pintados de vermelho-urucum: ciomáquia. $\mathrm{O}$ termo sugere um treinamento atlético de combate feito contra a 
própria sombra. Esse erudito do passado encerra sua descrição dizendo: por contar com os selvagens naturais e com marinheiros que de fato faziam o tráfico e tinham vivido no Brasil, tudo aquilo parecia ser "verdade e não simulado".

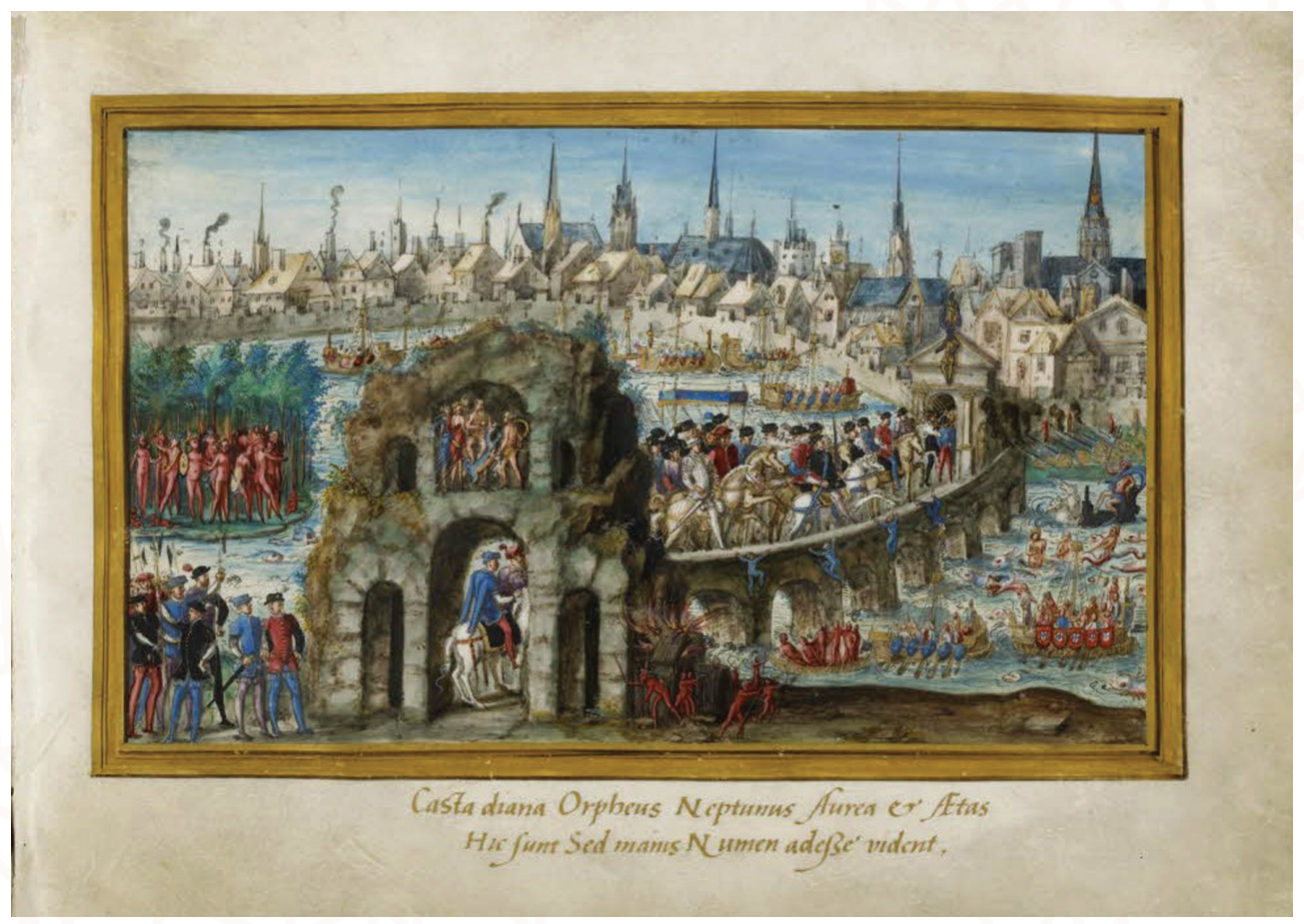

Figura 29 - Cortejo sobre a ponte na versão manuscrita

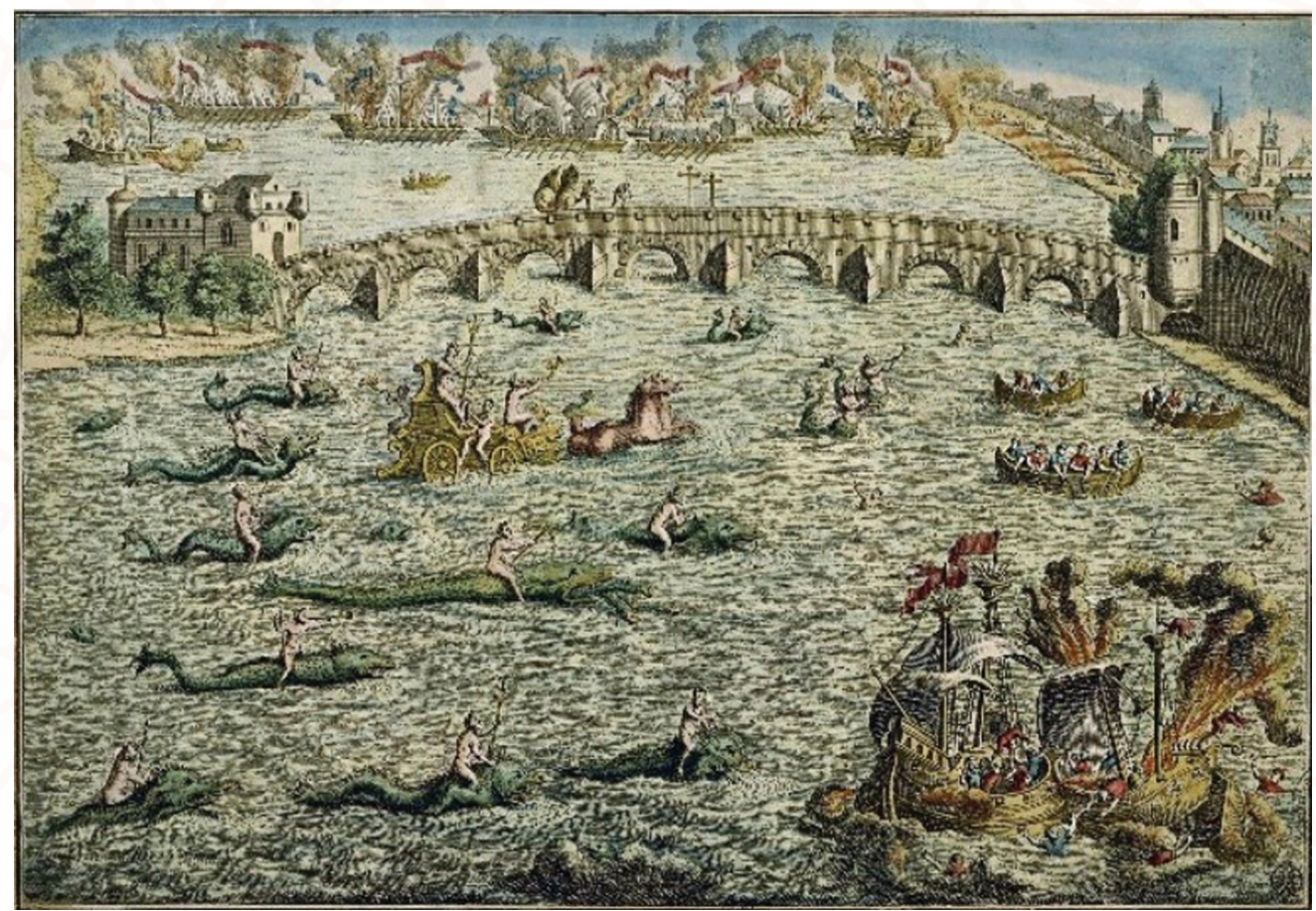

Figura 30 - Imagem da naumaquia, atribuída à mesma festa 
O interesse de historiadores por fenômenos da cultura tem estimulado o surgimento de muitas interpretações sobre os espetáculos públicos no Renascimento, o que ampliou recentemente as informações sobre a situação em que foram produzidos. Michael Wintroub nos informa, por exemplo, que as nove pessoas responsáveis pela festa da entrada real, registradas nos arquivos municipais de Rouen, pertenciam à classe da "nobreza de robe". Cinco dos seis membros do conselho municipal que as designaram para a função eram membros de uma confraria aristocrática de poetas cultores da virgem, chamada Puy de Palinod (WINTROUB, 2001, p. 498). E de fato parece haver uma inspiração no cristianismo humanista nas imagens finais do espetáculo da entrada: quando o rei cruza o rio e se depara com o mais apolíneo dos arcos de triunfo da festa, erigido já na cidade. Ali encontra uma alegoria da Idade do Ouro. É ao final do desfile que o soberano contempla a imagem do Heitor da llíada, apresentado como seu antepassado direto, ou vê as imagens edênicas dos campos elísios gregos onde seu pai, o rei François I, parece se abraçar à Fortuna no jardim. É esse desenlace que faz com que o pesquisador entenda a festa de 1550 como uma espécie de narração colecionista planejada por uma nobreza que mudava de condição histórica e por isso apresentava as cenas guerreiras (dos tupinambás e da antiguidade mítica) como realidades de barbárie a serem superadas por um "ideal ciceroniano de civilização baseada na eloquência, na erudição e na piedade" (WINTROUB, p. 500). A barbárie apresentada, assim, não seria apenas a dos brasileiros, misto de selvageria e de primitivismo paradisíaco, mas a dos próprios franceses, que deveriam mudar de posição diante da Europa culta.

Se a intepretação faz sentido do ângulo das disputas culturais e políticas europeias, em meio à nova mobilidade de classes de um século de guerras, é igualmente verdade que o papel concreto dos colaboradores burgueses não foi pequeno, ainda mais quando lemos o episódio do ponto de vista da colonização em curso. Ainda que o encaminhamento cênico se dirija a alegorizações líricas e espiritualizantes, predomina na festa a dramaticidade das lutas de guerra, a sonoridade bélica dos passos das tropas e do colorido vermelho do fogo mercantil mundializado.

Já se disse em tom de piada que a festa de Rouen contém o primeiro registro de brasileiros se divertindo na Europa. E de fato o encontro parece ter 
sido amistoso, a despeito das muitas mortes de índios ocorridas sempre que atravessavam o Atlântico. Em 1550, a relação de trabalho com os tupinambás ainda era de escambo, sem que houvesse ainda o interesse declarado dos franceses pela exploração colonial. Isso ocorreu logo, cinco anos depois, quando Villegaignon propôs o projeto da França Antártica ao rei. Os índios do Brasil podiam ainda ser símbolos para uma nova heráldica letrada cortesã na medida em que dialogavam como parceiros de práticas extrativistas do comércio normando. Podiam, assim, entrar no espetáculo como figuras representáveis, submetidos à hierarquia de uma festa que almejava alegorizar a unidade de um poder real e que expressava contradições entre os interesses bélicos dos cavaleiros, da nobreza culturalizada, da igreja politizada e do capitalismo comercial emergente: entre a teatralidade alegórica de sentidos múltiplos e o realismo concreto e performático da atualidade econômica. Nesse sentido, é possível dizer que a mais arcaica das presenças cênicas em Rouen (a dos índios do Novo Mundo) era também a mais atual: infiltrava a materialidade móvel do mundo das trocas no idealismo do conjunto.

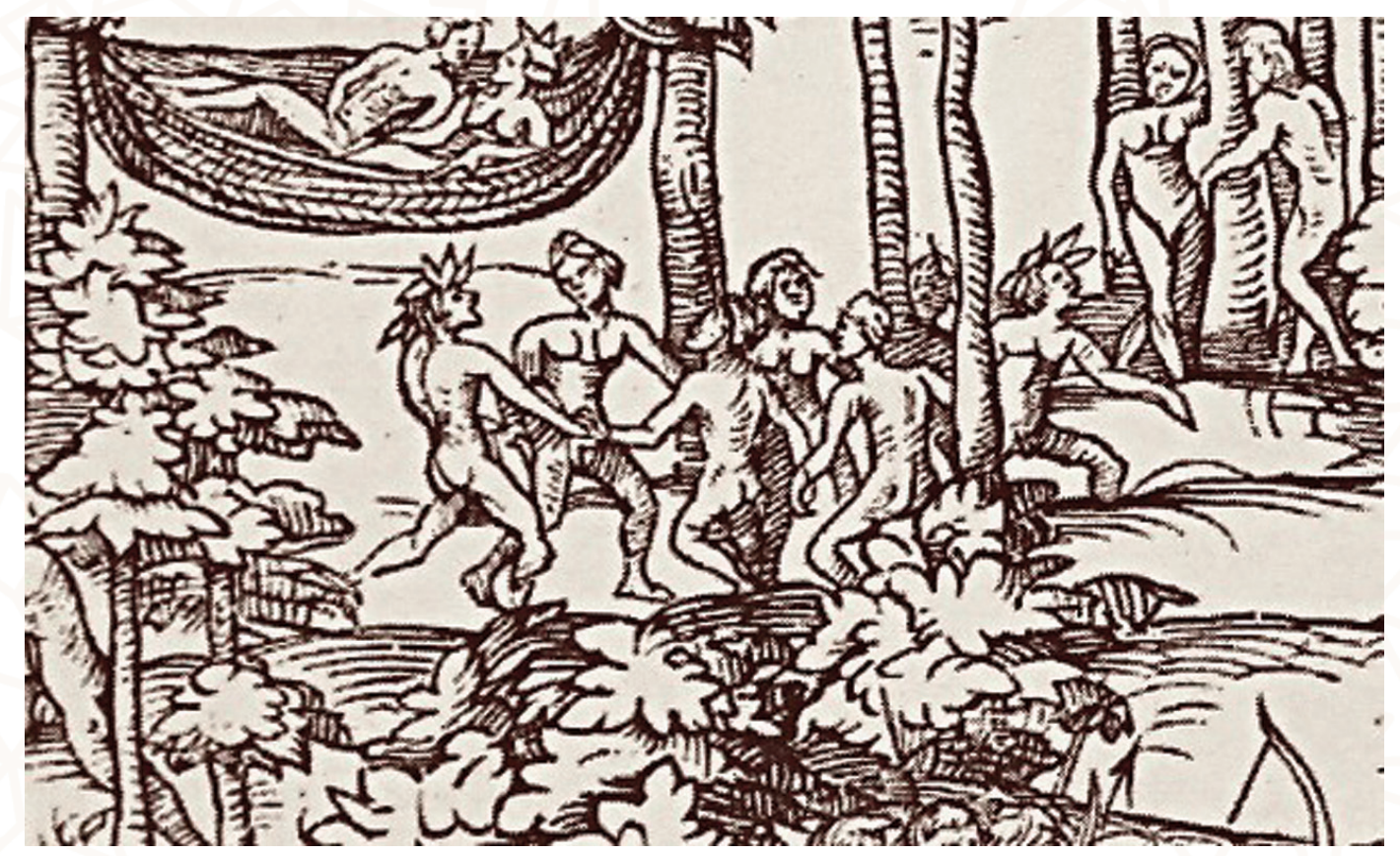

Figura 31 - Roda de dança em detalhe da versão impressa

É impossível imaginar o que essa experiência significou para aquele grupo de cinquenta índios. Um pequeno detalhe da imagem, entretanto, sugere um ponto de atrito cultural que pode servir para que se entenda a complexa 
incorporação posterior de formas culturais da elite europeia no imaginário popular do Brasil. É um dos poucos momentos lúdicos da entrada, tratando-se talvez de um espetáculo interno: uma dança feita em roda (Figura 31).

Os cronistas do Brasil no século costumam destacar o grande gosto e habilidade dos tupinambás no canto improvisado e na dança, elementos fundamentais de suas práticas rituais. Por outro lado, a imagem da roda de Rouen - em que estão de mãos dadas - não corresponde às descrições célebres de autores como Léry, Thevet, Staden e Gabriel Soares de Sousa, que sugerem outro modo característico de dança circular, feito com os corpos mais próximos, mão direita na cintura, braço esquerdo pendente, pé direito batendo no chão, o compasso marcado pelo maracá.

\section{Aspectos da teatralidade tupinambá}

Mais importante do que a forma, é pensar que não há registro na crônica tupinambá de qualquer dança, canto ou ato cênico realizado de modo profano, sem função mágica. Fosse o que fosse essa teatralidade tupinambá, ela se dava como tarefa ritual diante da guerra, da morte ou de outros grandes acontecimentos da vida coletiva. Não havia separação estética no sentido moderno na medida em que o sagrado e o profano não se distinguiam. Nos ciclos de bebedeira com cauim, que estimulavam as danças e cantos preparatórios à antropofagia, eram frequentes os olhos virados como em rituais de transe, conforme registra Jean de Léry?

Numa sociedade tão interessada em realizações de beleza, em que o corpo de homens e mulheres era cuidadosamente depilado como demarcação da diferença em relação aos animais, em que os adornos e enfeites eram feitos com cuidado extremo, todas as realizações que nós chamaríamos de estéticas surgiam para deflagrar a instauração de um real possível, numa concepção diferente da nossa em relação à função da beleza. Hans Staden (1974, p. 132) relata um encontro com o principal líder tupinambá do litoral sudeste do Brasil, o tamoio Cunhambebe (Figura 32). Após a captura de

7 "Mas é principalmente quando emplumados e enfeitados que matam e comem um prisioneiro de guerra em bacanais à moda pagã, de que são sacerdotes ébrios, que se faz interessante vê-los rolar os olhos nas órbitas" (LÉRY, 1980, p. 132). 
inimigos tupiniquins em São Sebastião, Cunhambebe tem diante de si um cesto cheio de carne humana, defumada após um sacrifício. Ele come uma perna. O alemão pergunta a ele: "se um animal irracional não come outro animal, por que um homem come outro homem?". O chefe índio dá uma mordida e diz: "Eu sou uma onça".

Na mesma tarde, Cunhambebe forma uma roda com seus guerreiros. Os prisioneiros tupiniquins que em breve serão mortos devem dançar, cantar e marcar o ritmo com os maracás mágicos. E cumprindo um ritual conhecido por vencidos e vencedores, cada prisioneiro, futura vítima, diz sua fala teatral com fúria e orgulho: "Vocês nos capturaram, mas isso não importa. Um guerreiro valoroso morre na terra do inimigo. [...] E os nossos - logo se vingarão em vocês". Ao que os outros, os vencedores, respondem: "Vocês já mataram muitos dos nossos, nós os vingaremos em vocês".

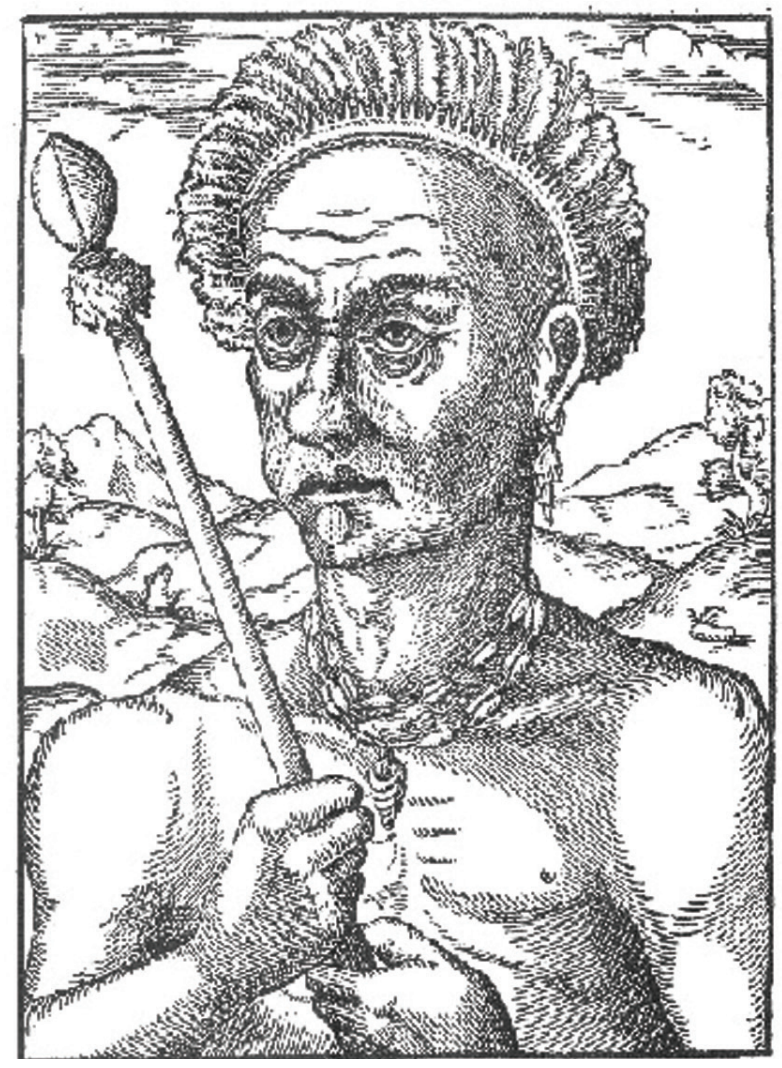

Figura 32 - Retrato do rei Cunhambebe, na edição de André Thevet e Jean Cousin, xilogravura de 1575

Ao matar o contrário, o vingador ganhava um novo nome, confirmado em público após o rito da antropofagia e só pronunciado em voz alta na ocasião 
certa. A antropóloga Manuela Carneiro da Cunha observa que a vingança é "a instituição por excelência da sociedade tupinambá” (CUNHA, 2009, p. 84) porque seu ciclo estabelece a conexão guerreira entre as gerações do passado e do futuro. Por outro lado, Cunhambebe não foi só irônico. Ao certo já possuía o nome de uma onça, animal que também era ocasionalmente morto em terreiro, como se fosse um inimigo humano, em semelhante cerimônia ritual de tomada de nome, com os mesmos adornos, pinturas e paramentos.

São muitos os exemplos desse pensamento mítico e artístico em que o mesmo e o outro transitam entre si, em que as invenções musicais, plásticas e corporais surgem como produção da continuidade da vida. Ouvi do sertanista Orlando Villas-Bôas o seguinte relato, observado no Xingu do século XX: uma jovem mulher índia fabricava vasos, pintando cuidadosamente neles motivos geométricos. Logo vinham as crianças pequenas que brincavam por perto, pegavam um desses vasos e quebravam. Ela seguia fazendo vasos, agora sabendo que eles seriam quebrados, e os pintava com o mesmo cuidado. $O$ sertanista pergunta: por que você pinta se sabe que eles vão quebrar? Ela responde: se eu não pintasse não seriam vasos.

Essa mesma atitude fazia com que no Século XVI, entre os tupinambás, no dia do grande sacrifício do prisioneiro inimigo, e do subsequente rito antropofágico, a vítima se apresentasse toda paramentada para a morte. Pequenas penas coloridas, as mais belas, eram coladas com mel e cobriam parte de seu corpo. Os pés eram pintados de vermelho, outras partes de preto. Adornos variados, guizos.

Assim, como se fosse uma entidade mítica, a vítima era amarrada pela cintura a uma corda sagrada, a muçurana, tendo que responder aos ataques feitos com palavras, pedras e cacos de vasos, para demonstrar coragem diante da morte próxima, anunciando que seus parentes a vingarão (Figura 33). Seu matador, que receberá o novo nome, aparece no terreiro da tribo após cumprir um retiro espiritual, cheio de adornos na cabeça, braços, cintura e pernas, no máximo do esplendor de um guerreiro, entrando em cena no papel de matador com o grande tacape, a ibirapema, objeto que foi consagrado pela decoração das mulheres. Com esse instrumento, após nova luta, meio simulada, meio real, a cabeça decorada do inimigo é estraçalhada - tal como o vaso da criança (Figura 34). 


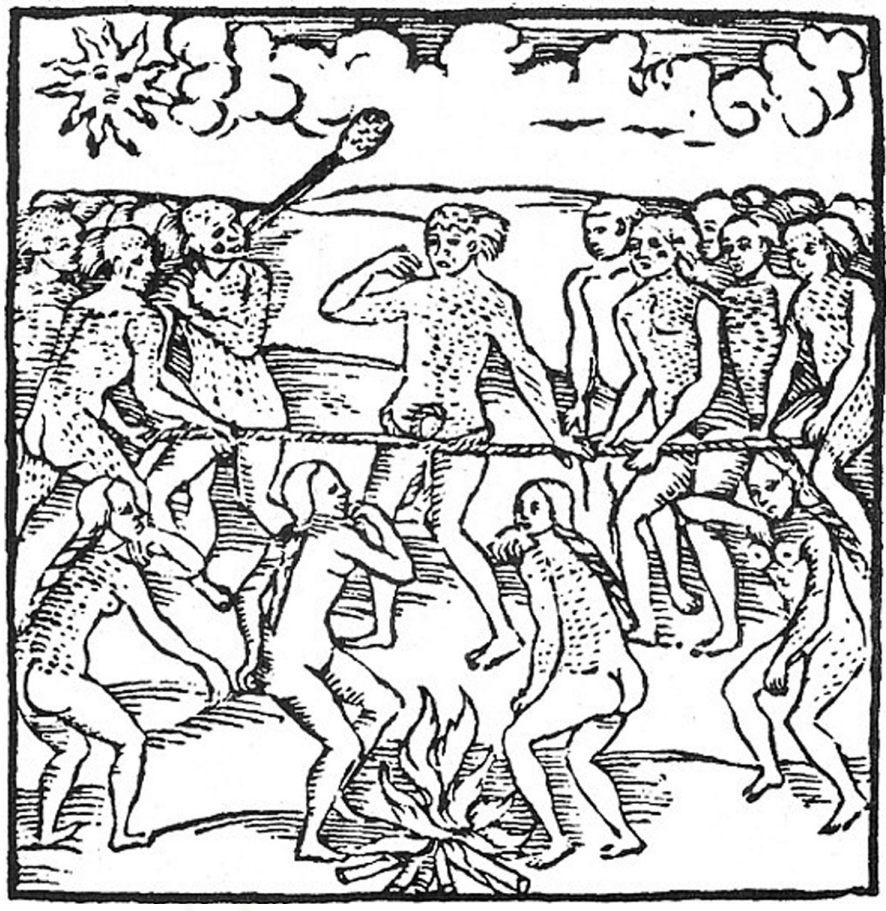

Figura 33 - Morte do prisioneiro em gravura do livro de Hans Staden

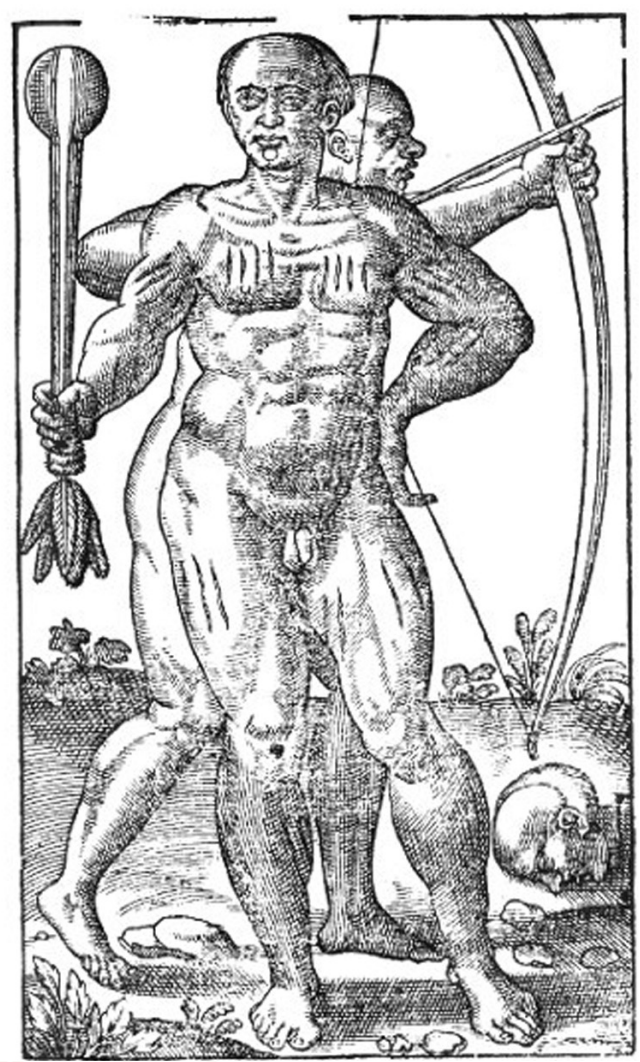

Figura 34 - Tupinambá em gravura de 1594, reedição da obra de Jean de Léry 
Os tupinambás foram exterminados ou expulsos do litoral brasileiro poucas décadas depois da festa de Rouen, mas um eco de sua presença na Europa entrou na filosofia moderna. O grande ensaísta Montaigne conheceu três índios naquela mesma cidade, doze anos depois da entrada triunfal de Henrique II, num encontro com o novo rei Carlos IX. Montaigne escreveu um famoso ensaio chamado "Os canibais", que dizem ter influenciado o Caliban de Shakespeare e mesmo o bom selvagem de Rousseau. Montaigne anotou canções dos índios. Uma delas certamente é tupinambá. Ela tem como versos finais: "Não reconheceis a substância dos membros de vossos antepassados que ainda se encontram em mim? Saboreai atentamente, sentireis o gosto da vossa própria carne" (MONTAIGNE, 1980, p. 105).

Um outro registro dessa perdida voz tupinambá, recolhido por Montaigne, é ainda mais atual. Diz respeito ao mundo do capital que ali começava. Quando perguntaram aos índios o que pensavam da rica cidade de Rouen, eles manifestaram uma estranheza: a de que houvesse gente bem alimentada e gozando as comodidades da vida de um lado e, de outro, muitos esfomeados, miseráveis, mendigando à porta dos primeiros. Os índios denominaram a esses infelizes de pessoas "pela metade". O mais extraordinário, segundo Montaigne (1980), aos olhos dos tupinambás, era que essas metades de gente pudessem suportar "tanta injustiça sem se revoltarem e incendiarem as casas dos demais" (p. 105).

\section{Transposições da cena do triunfo no Brasil}

A teatralidade híbrida da Europa do século XVI - tal como se viu nas imagens do triunfo de Rouen - traduz o fim de um ciclo católico monárquico e o começo de outro, em meio às guerras da religião, disputas nacionais, capitalismo comercial e imaginário filosófico, poético e jurídico do indivíduo moderno. Nas colônias, entretanto, a modernização europeia reinventava a mais arcaica das práticas de exploração, o trabalho escravo, a serviço de um pragmatismo econômico sem freios.

Os tupinambás, que escolheram comerciar com os franceses e combater os portugueses, só poderiam ter ainda lugar no teatro do Brasil português do século XVI enquanto a dinâmica cultural de um capitalismo escravista 
e católico não estivesse plenamente implantada, o que se concretizaria em pouco tempo.

Em 1549, a Coroa Portuguesa instalou um governo colonial na Bahia. No navio do primeiro governador veio também um grupo de jesuítas, oriundos de Coimbra, com a missão de catequisar índios e ajudar na regulação moral dos colonos. A cultura aristocrática que assim desembarcava era muito militarizada e sustentava-se na associação com o catolicismo militante da Contrarreforma. A Companhia de Jesus, apesar de seu pouco tempo de existência, tinha forte apoio no Vaticano, e já estava próxima das cortes de Portugal e Espanha. Especializara-se em ações educacionais e missionárias em torno de colégios, modelo que seria exportado ao Brasil. Os jesuítas aprenderam em pouco tempo a importância das práticas da teatralidade pública como demonstração de força da igreja. Praticamente todas as formas de teatralidade de que temos registro na colônia do Brasil na segunda metade do século XVI estão sob sua influência direta ou indireta.

Um dos mais interessantes registros da cultura jesuítica daquele tempo, e que descreve alguns espetáculos, é um relato feito pelo irmão Fernão Cardim, que passou dois anos no Brasil como secretário de um padre visitador que veio de Portugal para fiscalizar o trabalho geral da ordem.

Cardim chega ao Brasil em 1583, década em que a alternativa econômica da produção de cana-de-açúcar para exportação se mostrava a melhor possibilidade para a terra, o que estimulava o crescimento do tráfico de homens escravizados da África, em pouco tempo um dos maiores negócios da colônia.

Na viagem ao Brasil, o ilustre visitador da Companhia de Jesus traz na bagagem uma grande quantidade de relíquias para serem doadas às igrejas locais. Diante da dificuldade do diálogo com índios e colonos, os jesuítas na América desenvolveram uma especial atenção aos elementos fetichistas do culto católico, reinventados na Europa quinhentista em torno das lendas de santos. Daí a disseminação das celebrações de padroeiros materializadas por relíquias - cabelos, ossos e arcadas dentárias que concretizavam a permanência do poder místico do santo em seus restos mortais. A chegada do visitador, então, foi motivo de uma série de festas de recebimento, tanto do objeto dadivoso como do jesuíta ilustre que o doava. 
Os religiosos no Brasil desenvolveram de modo muito cuidadoso essa teatralidade da fé que utilizava padrões muitos semelhantes aos das exibições do poder dos reis da Europa, mas se adaptava aos elementos locais. O osso do santo europeu entraria na capelinha tropical assim como Henrique II entrou em Rouen: com procissão da elite urbana, decoração no caminho, carros alegóricos, encenações em tablados. E nos séculos seguintes os arcos de triunfo seriam prática recorrente.

Algo do hibridismo da teatralidade europeia do período - em que na mesma época e lugar conviviam diálogos pastorais ingênuos, teatro erudito renascentista, moralidades medievais e procissões festivas - migrava para o Brasil. A novidade é que essa associação entre a herança dos mistérios medievais e o didatismo de uma cena pública que ostentava o poder de seu próprio aparato seria reorientada para o diálogo com colonos violentos, com a nobreza militar e com os índios disputados como força de trabalho. As contradições dos espetáculos do período traduzem esse conflito não resolvido: a incorporação dos índios na cristandade (autorizada pela bula papal que "generosamente" reconhecia que eles possuíam alma) esbarrava nos interesses dos colonos em escravizá-los. É nessa tensão que o teatro jesuítico ainda expressa formas da diferença social.

Logo no dia de sua chegada, em maio de 1583, o visitador doou uma preciosidade: o crânio de uma das lendárias virgens que acompanharam Santa Úrsula em seu martírio. Seria o terceiro, pois a cidade já dispunha de dois outros crânios. Àquela altura essas santas eram conhecidas como As onze mil virgens, numa multiplicação fantástica das onze originais. Seu culto se difundia por Portugal, a ponto de haver ainda hoje uma relíquia do corpo de Úrsula na Sé de Lisboa, enviada da Colônia. Os estudantes do colégio jesuítico de Salvador, na Bahia, vários deles filhos da elite local, organizaram para o recebimento uma grande encenação. Relata Cardim (1980):

Trouxe o padre uma cabeça das Onze mil virgens, com outras relíquias engastadas em meio corpo de prata, peça rica e bem-acabada. A cidade e os estudantes the fizeram um grave e alegre recebimento: trouxeram as santas relíquias da Sé ao Colégio em procissão solene, com flautas, boa música de vozes e danças. A Sé, que era um estudante ricamente vestido, Ihe fez uma fala do contentamento que tivera com sua vinda; a 
Cidade Ihe entregou as chaves; as outras duas virgens, cujas cabeças já cá tinha, a receberam à porta de nossa igreja; alguns anjos as acompanharam, porque tudo foi a modo de diálogo. Toda a festa causou grande alegria no povo, que concorreu quase todo. (p. 143)

Nessa cena, em que os estudantes personificaram a cidade e a igreja, a relíquia, tal como um rei mundano, tornava-se não só o ator, mas o espectador central. E, como assinala o cronista, tudo feito "a modo de diálogo". O padrão do jogo coral é retomado e desenvolvido no ano seguinte. Em 21 de outubro de 1584, após ser fundada a confraria das Onze Mil Virgens a pedido dos alunos dos jesuítas, ocorre uma nova festa em que se trasladam as ossadas, com uma procissão cênica muito maior, realizada após grande missa. Cardim descreve esse espetáculo com termo mais preciso: um triumpho das santas. A rigor, essa modalidade cênica em que a relíquia entrava na igreja como se fosse uma criatura viva não correspondia exatamente à dinâmica processional do rei que ocupa a cidade nem reproduzia a cena simultaneísta da cristandade misteriosófica medieval; o que parece surgir, ainda sem grande atrito cultural, era uma amálgama de tradições em que a festa, ironicamente, também parecia celebrar um ponto de vista mortuário, o da caveira, tamanha a estranheza de sua chegada à colônia, conduzida por uma ordem - a dos jesuítas - que se empenhava em mediar relações políticas e sociais muito conflituosas diante do descontrole com que as práticas econômicas se difundiam por aqui.

Reavivada pelos jesuítas, essa tradição do culto católico às relíquias, tão combatida pelos protestantes naquelas décadas de guerras religiosas, remonta ao início do século XIII. Seu crescimento se deve à invasão de Constantinopla na quarta cruzada, ocorrida entre 1202 e 1204. Os saques decorrentes geraram um enorme interesse comercial por restos sagrados. Na relação de 1247 das relíquias da coleção de Luís IX, por exemplo, organizadas na bela Santa Capela de Paris, construída para este fim, constavam, além dos muitos ossos de santos, materiais incríveis, como o leite da Virgem Maria e o sangue de Cristo, ou mesmo "uma cruz dita de triumpho" que os imperadores cristãos do passado tinham o costume de portar nos dias de batalha (SAINTYVES, 1930, p. 499).

Essa segunda procissão das virgens mártires em Salvador alude, portanto, a uma tradição em que o triunfalismo católico e o monárquico já surgiam 
fundidos na Europa, mas que por aqui enfrentava as dificuldades de trato com colonos que preferiam inventar regras próprias de exploração.

Naquela tarde, rudimentos de diálogos teatrais surgiam em torno do carro-barco que levava os atores. Anota Cardim (1980):

E ela acabada [a missa], se ordenou a procissão dos estudantes, aonde levámos debaixo do pálio três cabeças das Onze mil virgens, e as varas levaram os vereadores da cidade, e os sobrinhos do Sr. Governador. Saiu na procissão uma nau à vela por terra, mui formosa, toda embandeirada, cheia de estudantes, e dentro dela iam as Onze Mil Virgens ricamente vestidas, celebrando seu triumpho. De algumas janelas falaram à cidade, colégio, e uns anjos todos mui ricamente vestidos. Da nau se dispararam alguns tiros de arcabuzes, e o da de antes houve muitas invenções de fogo, na procissão houve danças, e outras invenções devotas e curiosas. À tarde se celebrou o martírio dentro na mesma nau, desceu uma nuvem dos Céus, e os mesmos anjos Ihe fizeram um devoto enterramento. A obra foi devota e alegre, concorreu toda a cidade por haver jubileu e pregação. (p. 165)

Outra descrição da mesma encenação surge numa carta ânua de José de Anchieta (1984), que menciona a seda do pálio e o relicário que envolvia as cabeças, e informa que a nau cênica foi "montada com perfeição sobre rodas de madeira, tão escondidas, que delas nada sobressaía" (p. 368).

Anchieta (1984) oferece mais detalhes sobre as estações, momentos em que as "representações" ocorriam como diálogos entre as intervenções recitadas pelas figuras e respostas corais:

Nessa nau era transportada Santa Úrsula e suas companheiras, sobre as quais sobrepairava um Anjo com a palma na mão, e a exortar o bataIhão à conquista da coroa do martírio. A tal pregão, acolhido com rosto não turbado, mas feliz, a comandante e todas as mais com voz sonora, respondiam em uníssono estarem prontas a dar, por Jesus, esposo de suas almas, o sangue e a vida. Terminados tais diálogos, prosseguiu a nau o caminho iniciado. À última alocução do Anjo, desfraldaram-se estandartes vermelhos e soaram os estampidos dos morteiros, como sinal de um glorioso triunfo. (p. 368)

$\mathrm{Na}$ parte da tarde, ainda informa Anchieta (1984), ocorreram novas encenações, em que os corpos degolados e cobertos de sangue das virgens, 
carregados pelos anjos, foram depositados no sepulcro em meio a "suaves canções". Isso tudo, observa,

com tamanho realismo que, não apenas os espectadores, mas os próprios atores, deixando-se dominar pela compaixão, desataram em prantos. Exibições, estas e outras que - como a experiência demonstra concorrem para que se reúnam, vindas por terra e por mar, verdadeiras multidões, aumentado assim o número das confissões, com o proveito das almas. (p. 368)

As peças do teatro de Anchieta aproveitaram-se muito dos padrões dessa teatralidade pública que combinava coralidade religiosa, estampidos militares e imaginário sangrento. E festas religiosas como essa acabaram por entrar no calendário das cidades coloniais, com a mesma combinatória livre de repertório católico e inesperados elementos indígenas, africanos ou mesmo greco-latinos. A própria procissão das Onze Mil Virgens seguiu instituída no calendário de Salvador - e repetida em cidades como São Paulo - até o início do século XVIII, período em que já ocorria como procissão de mascarados (CAMPOS, 2001). É um exemplo, entretanto, em que a interação crítica com formas culturais dos índios do Brasil não ocorria, como depois ocorrerá no teatro de Anchieta.

Poucos dias depois, em novembro de 1584, o mesmo Gouveia e seu secretário Cardim visitaram uma aldeia indígena não muita distante de Salvador, tutelada pelos jesuítas. O caminho até lá era percorrido de canoa, através de um rio. A certa altura, os religiosos são abordados por um grupo de índios, entre eles alguns principais, os morubixabas. O grupo indígena - e é provável que houvesse tupinambás entre eles, pois eram aldeados - se aproxima com vinte canoas decoradas, embandeiradas, tocando tambores e flautas. Fernão Cardim nos informa que os índios vieram "providos de mui formosos arcos e flechas mui galantes". Começaram então a fazer a representação de um combate, com "muitas ciladas no rio", isto é, simularam tocaias e aparições repentinas, com grande gritaria, e ao mesmo tempo entoaram o tradicional "Ereiupe" tupi (a saudação de boas-vindas que significa "Você veio"). Os indígenas chegaram ao ponto de cercar e simular a prisão do jesuíta visitador. Cardim (1980, p. 166) conclui o episódio dizendo que um menino 
se aproximou da canoa do religioso e lhe disse em sua língua: "Em tempo de guerra e cerco, como estás desarmado?". E lhe meteu arcos e flechas na mão para que o padre participasse da luta.

Essa passagem é mais do que curiosa. Para alguns pesquisadores, seria um inédito exemplo de teatro indígena profano. A tradição de comentadores da cultura tupinambá chega a comparar a cena a uma tradicional saudação lacrimosa que as tribos costumavam dar a seus visitantes quando visitavam sua aldeia ou se retornava de viagem longa. Mesmo o maior estudioso da religião tupinambá, Alfred Métraux, sugere haver aí algo que pode ser considerado uma espécie de "saudação agressiva". Entretanto, um jogo teatral assim exposto, fundado numa representação deliberada, é incomum demais no imaginário indígena descrito pela literatura quinhentista. Acredito que, na verdade, estamos diante de uma naumaquia europeia adaptada, um combate aquático, como aquele visto há pouco, forma espetacular que poderia, quem sabe, ter sido aprendida de corpo presente por alguns daqueles índios, poucos anos antes, na entrada real de Rouen.

Na parte final desta conferência, apresentarei um dos mais significativos exemplos dessa cena triunfalista dos jesuítas do Brasil, a encenação de Auto de S. Lourenço, de Anchieta ${ }^{8}$. É um dos últimos instantes em que os tupinambás entraram em cena no século XVI, não mais como atores, mas como personagens, figurações dos inimigos da plateia cristã de índios que os assistia, como diabos dialogantes ao mesmo tempo reais e ficcionais.

\section{Rarefação dramática}

No mesmo ano em que estreou o Auto de S. Lourenço, 1587, Cristopher Marlowe estreava em Londres seu Tamerlão. Era o início de um breve ciclo em que o teatro europeu, em particular o elisabetano e o do Século de Ouro espanhol, antes da hegemonia do palco italiano e do drama burguês, conheceria a individuação como problema trágico, em meio a um mundo de guerras da fé e espectros do passado. No Brasil, no mesmo ano, os tupinambás ainda apareceriam no teatro de José Anchieta como demônios, numa comemoração de

8 Conforme explicado na nota 1. O parágrafo final, intitulado Rarefação dramática, encerrou a conferência do IFTR, após a descrição do contexto do Auto de S. Lourenço, aqui suprimida. 
sua expulsão e chacina na Baía da Guanabara, lugar onde a peça foi encenada. Ainda não estavam exterminados, eram considerados inimigos reais. Nos séculos seguintes, mesmo um drama literário como esse, notável documento da barbárie, escrito pelo santo evangelizador do Brasil, já não seria possível na colônia. As vozes contrárias aos processos do capital em breve não teriam mais existência social, e o elemento diabólico (e também o dialógico) se tornariam abstratos ou proscritos, conforme se extinguia o escambo nas práticas do mercantilismo e o escravismo se desenvolvia numa economia de exportação. A figuração da individualidade não surgiria em cena sequer como problema, porque o outro estava ausente. Nem uma ciomáquia de elite fazia mais sentido, porque, como registra um texto de Marx (2011), "o comércio separou a sombra do corpo e introduziu a possibilidade de possuí-los separadamente" (p. 163). O imaginário tradicional dos tupis do litoral e suas dinâmicas de êxtase se esconderam nos sertões, se dissolveram nas formas culturais do catolicismo popular ou se transmudaram em gestos sincréticos de ritos secretos. O mesmo ocorreria com as práticas africanas desenraizadas, que também sobreviveram travestidas de triunfalismo monárquico, de combates entre cristãos e mouros, de imaginário náutico. Ainda hoje, é a lírica coral dessa religiosidade popular e de suas danças dramáticas que testemunha aquele atrito antigo entre esboços de individuação e a sabedoria coletiva antiga. E mesmo nossos homens de letras seguiriam sonhando com esse diálogo impossível, idealizando o projeto da liberdade e da autonomia, as formas culturais da subjetividade europeia, que aqui não tinham lugar nem como ideologia, o que instaurava o pior dos mundos. A melancolia diante de uma Razão irrealizável não os deixava ver que o atraso local correspondia ao avanço do capitalismo global. Sentiram-se assim, por muito tempo, como exilados na própria terra. Enquanto isso, a vida popular seguia seus caminhos, porque desde cedo entendeu que a colônia era a vanguarda de um mundo em que o próprio dinheiro se tornaria o verdadeiro "indivíduo da riqueza universal".

\section{Referências bibliográficas}

ANCHIETA, J. Cartas: correspondência ativa e passiva. São Paulo: Edições Loyola, 1984. v. 6. (Obras completas). 
ANÔNIMO. L'entrée à Rouen du roi et de la reine, Henri II et Catherine de Médicis: d'après la relation imprimée en 1550. Ed. fac-sim. Rouen: Imprimerie de Experance Cagniard, 1885. Disponível em: <https://goo.gl/jaCqBS>. Acesso em: 17 out. 2017.

CAMPOS, J. S. Procissões tradicionais da Bahia. 2. ed. Salvador: Secretaria de Cultura e Turismo; Conselho Estadual de Cultura, 2001.

CARDIM, F. Tratados da terra e gente do Brasil. Belo Horizonte: Itatiaia, 1980.

CHARTROU, J. Les entrées solennelles et triomphales à la Renaissance (14841551). Paris: les Presses Universitaires de France, 1928.

COULANGES, N. D. F. A Cidade Antiga: estudo sobre o culto, o direito e as instituições da Grécia e de Roma. Tradução Fernando Aguiar. Lisboa: Livraria Clássica Editora, 1971.

CUNHA, M. C. Cultura com aspas: e outros ensaios. São Paulo: Cosac Naify, 2009.

DENIS, F. Uma festa brasileira celebrada em Rouen em 1550: teogonia dos antigos povos do Brasil, um fragmento recolhido no século XVI: poemas brasílicos de Cristóvão Valente. São Bernardo do Campo: Bazar das Palavras; Usina de Ideias, 2007.

DUVIGNAUD, J. Sociologie du Théâtre: essai sur les ombres collectives. Paris: Presses Universitaires de France, 1965.

LÉRY, J. Viagem à terra do Brasil. Belo Horizonte: Itatiaia, 1980.

MARX, K. Grundrisse. São Paulo: Boitempo, 2011.

MONTAIGNE, M. Ensaios. 2. ed. São Paulo: Abril Cultural, 1980.

PLUTARCO. Las vidas paralelas. Tradução Antonio Ranz Romanillos. Madrid: La Imprenta Nacional, 1830. v. 2.

SAINTYVES, P. En marge de la légende dorée: songes, miracles et survivances: essai sur la formation de quelques thèmes hagiographiques. Paris: Émile Nourry, 1930.

STADEN, H. Duas viagens ao Brasil. Belo Horizonte: Itatiaia; São Paulo: Edusp, 1974.

SUETÔNIO. Los doce césares. Buenos Aires: Librería El Ateneo, 1951.

WEISBACH, W. Trionfi. Berlin: G. Grotesche Verlagsbuchhandlung, 1919.

WINTROUB, M. L'ordre du rituel et I'ordre des choses: I'entrée royale d'Henri II à Rouen (1550). Annales. Histoire, Sciences Sociales, Paris, v. 56, n. 2, p. 479505, 2001.

Recebido em 30/10/2017

Aprovado em 06/11/2017

Publicado em 26/12/2017 